\title{
From zero- to three-dimensional heterobimetallic coordination polymers with the $\left[\mathrm{Pt}\left\{\mathrm{SSC}-\mathrm{N}\left(\mathrm{CH}_{2} \mathrm{COO}\right)_{2}\right\}_{2}\right]^{4-}$ metalloligand
}

Received 00th January 20xx, Accepted 00th January 20xx DOI: $10.1039 / \times 0 \times x 00000 x$

\begin{abstract}
Phil Liebing, ${ }^{* a}$ Florian Oehler, ${ }^{b}$ Juliane Witzorke, ${ }^{a}$ and Marten Schmeide ${ }^{a}$
Heterobimetallic compounds of the type $\mathrm{M}_{2}^{\prime}\left[\mathrm{Pt}(\mathrm{L})_{2}\right]\left(\mathrm{L}=\mathrm{N}\right.$-dithioato-iminodiacetate, $\left.\left\{\mathrm{SSC}-\mathrm{N}\left(\mathrm{CH}{ }_{2} \mathrm{COO}\right)_{2}\right\}^{3-}\right)$ containing different bivalent, oxophilic metals $\mathrm{M}^{\prime}$ were prepared in a straightforward manner from $\left[\mathrm{Pt}\left(\mathrm{H}_{2} \mathrm{~L}\right)_{2}\right]$ and the respective metal acetates, $\mathrm{M}^{\prime}(\mathrm{OAc})_{2}\left(\mathrm{M}^{\prime}=\mathrm{Mg}-\mathrm{Ba}, \mathrm{Mn}-\mathrm{Cu}, \mathrm{Cd}\right)$. X-ray structure determination revealed that the products exist as zero- $(\mathrm{Mg})$, one- (Mn), two- (Fe, Co, $\mathrm{Ni}, \mathrm{Cd}$ ), or three-dimensional $(\mathrm{Sr})$ assemblies in the solid state. As a result, the water solubilities and thermal stabilities of the products cover much wider ranges than it has been seen with $\mathrm{M}_{2}{ }_{2}\left[\mathrm{M}(\mathrm{L})_{2}\right]$ compounds having different thiophilic metal centers $(\mathrm{M}=\mathrm{Ni}, \mathrm{Pd}, \mathrm{Pt})$. While most of the compounds show a typical diamagnetic (Mg-Ba, $\mathrm{Cd})$ or paramagnetic ( $\mathrm{Mn}, \mathrm{Co}, \mathrm{Ni}, \mathrm{Cu}$ ) behaviour at ambient temperature, for $\mathrm{Fe}_{2}\left[\mathrm{Pt}(\mathrm{L})_{2}\right] \cdot 4 \mathrm{H}_{2} \mathrm{O}$ an antiferromagnetic interaction of the Fe atoms is assumed.
\end{abstract}

\section{Introduction}

Coordination polymers (CPs) are of tremendous relevance due to their potential ability to form three-dimensional porous structures, so-called metal-organic frameworks (MOFs). ${ }^{1,2}$ In the recent decade, CPs containing more than one metal have attracted significant research interest, as they can exhibit completely different structures and properties than their homometallic analogs, offering new reaction patterns and novel fields of application. ${ }^{3-8}$ Since the metal-ligand connectivity in these compounds is often difficult to predict and to control, the development of rational synthetic strategies is of fundamental importance. In recent contributions, we have shown that dithiocarbamate-functionalized carboxylates (DTCCs) can coordinate selectively to a to a soft (thiophilic) and a hard (oxophilic) metal center at the same time.9,10 DTCCs are readily available from cheap starting materials, allowing an amino acid to react with carbon disulfide under alkaline conditions (Scheme 1). ${ }^{11}$ Heterobimetallic CPs with DTCC ligands are most conveniently synthesized in a sequential approach. This includes the complexation of the dithiocarbamate group with a soft metal such as bivalent nickel, palladium, or platinum in a first step, and the isolation of the so-obtained "metalloligand" by protonation of the carboxylate groups. The heterobimetallic target products are subsequently obtained when the protonated metalloligand is treated with an acetate of an oxophilic metal. Following this approach, we have prepared

\footnotetext{
a. Otto-von-Guericke-Universität Magdeburg, Chemisches Institut, Universitätsplatz 2, 39106 Magdeburg, Germany.

b. Martin-Luther-Universität Halle-Wittenberg, Institut für Chemie, Kurt-Mothes-Str. 2, 06120 Halle (Saale), Germany.

Electronic Supplementary Information (ESI) available: Details on single-crystal structural analyses, Powder X-ray diffraction patterns, thermal analyses and magnetic measurements. CCDC 2032166-2032172 contain the crystallographic data for the reported compounds.
}

$\mathrm{Zn} / \mathrm{Pt} \mathrm{CPs}$ with various DTCC ligands, ${ }^{9}$ as well as $\mathrm{Zn} / \mathrm{Pd}$ and $\mathrm{Zn} / \mathrm{Ni}$ $\mathrm{CPs}$ with the iminodiacetic acid derived ligand \{SSC$\left.\mathrm{N}\left(\mathrm{CH}_{2} \mathrm{COO}\right)_{2}\right\}^{3-}(=\mathrm{L}){ }^{10}$ The CPs having bis(carboxylate) $\mathrm{Pt}(\mathrm{II})$ metalloligands derived from sarcosine and L-proline extend in one dimension, while the tetrakis(carboxylate) metalloligands $\left[\mathrm{M}(\mathrm{L})_{2}\right]^{4-}(\mathrm{M}=\mathrm{Ni}, \mathrm{Pd}, \mathrm{Pt})$ form two-dimensional assemblies with $\mathrm{Zn}^{2+}$ ions in the solid state. Thereby, the two-dimensional structures turned out to be thermally significantly more stable than the one-dimensional ones, whereas the variation of the thiophilic metal $M$ exerts a much smaller influence on the structures and thermal properties. We were now interested in $\mathrm{M}_{2}{ }_{2}\left[\mathrm{M}(\mathrm{L})_{2}\right]$-type compounds with $\mathrm{M}^{\prime}$ being divalent, oxophilic metals other than zinc. We report here the synthesis and extensive characterization of nine new heterobimetallic compounds from the $\mathrm{M}_{2}{ }_{2}\left[\mathrm{Pt}(\mathrm{L})_{2}\right]$ family, including alkaline-earth and transition-metal derivatives.

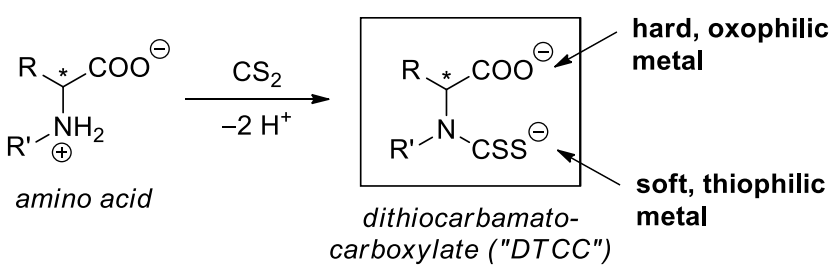

Scheme 1. General synthesis of DTCC ligands from amino carboxylic acids and their potential ability to coordinate hard and soft metal centres selectively $\left(R, R^{\prime}=\right.$ Alkyl residues; *potential chirality centre)

\section{Results and discussion}

Synthesis and characterization of compounds $\mathrm{M}^{\prime}{ }_{2}\left[\mathrm{Pt}(\mathrm{L})_{2}\right](2)$.

In accordance to our previously published results on zinc/platinum CPs, the most efficient synthetic strategy is the 
reaction of the protonated metalloligand $\mathrm{H}_{4}\left[\mathrm{Pt}(\mathrm{L})_{2}\right](\mathbf{1})$ with an excess metal acetate in aqueous solution. ${ }^{9}$ Following this procedure, we allowed to react 1 with several acetates of alkaline-earth and divalent transition metals (Scheme 2). The general outcome of these reactions is summarized in table 1 , showing that only a minority of the $\mathrm{M}^{\prime 2+}$ ions behave similar as $\mathrm{Zn}^{2+}$, forming soluble products. The corresponding heterobimetallic compounds $\mathrm{M}^{\prime}{ }_{2}\left[\mathrm{Pt}(\mathrm{L})_{2}\right]\left(\mathbf{2} ; \mathrm{M}^{\prime}=\mathrm{Mg}, \mathrm{Mn}, \mathrm{Co}, \mathrm{Ni}\right)$ could be isolated in their hydrated forms in very good yields upon precipitation with acetone. In all other cases $\left(\mathrm{M}^{\prime}=\mathrm{Ca}, \mathrm{Sr}, \mathrm{Ba}, \mathrm{Fe}\right.$, $\mathrm{Cu}, \mathrm{Cd}$ ), the products appeared to be poorly soluble in water and precipitated directly from the reaction solutions. The composition of the products $\mathbf{2}$ with their respective water content was determined by elemental analyses $(\mathrm{C}, \mathrm{H}, \mathrm{N}, \mathrm{S})$. Thereby, most of the crystalline products lost crystal water partially upon isolation and the water content of the final products was lower than that in the single-crystal structures (vide infra), which prevented a reasonable determination of the phase purity by powder X-ray diffraction. The only exceptions are $\mathbf{2 - S r}$ and $\mathbf{2 - C d}$, and for these compounds the powder diffraction patterns agreed excellently with the patterns calculated from single-crystal data (cf. Figures S8 and S9 in the Supporting Information).

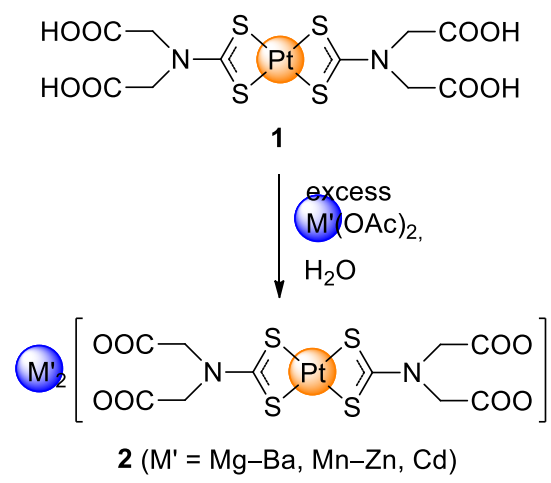

Scheme 2. Synthesis of the heterobimetallic compounds $\mathrm{M}_{2}{ }_{2}\left[\mathrm{Pt}(\mathrm{L})_{2}\right](\mathbf{2})$ from the protonated metalloligand $\left[\mathrm{Pt}\left(\mathrm{H}_{2} \mathrm{~L}\right)_{2}\right](\mathbf{1})$. The derivative with $\mathrm{M}^{\prime}=\mathrm{Zn}$ has been reported previously. ${ }^{9}$

Thermal analyses revealed that some of the compounds in their isolated hydrated forms (2-Ca, 2-Sr, 2-Ba, 2-Mn, 2-Ni, 2-Cd) show a well-defined dehydratization step below $200{ }^{\circ} \mathrm{C}$, while others (2-Mg, 2-Fe, 2-Co, 2-Cu) are less cleanly dehydrated upon heating and behave therefore similar as the previously reported 2-Zn (cf. Figures S10 and S11). ${ }^{9}$ The temperature of decomposition of the ligand scaffold is very different and ranges from $182{ }^{\circ} \mathrm{C}(\mathbf{2}-\mathbf{C u})$ to $470{ }^{\circ} \mathrm{C}(\mathbf{2}-\mathbf{S r})$. Interestingly, among the alkaline-earth metal derivatives $\mathbf{2}-\mathbf{S r}$ is the thermally most stable product, while the decomposition temperatures for $\mathbf{2 - C a}$ and 2-Ba are significantly lower and similar at $430^{\circ} \mathrm{C}$.

Determination of the magnetic moment at room temperature revealed a typical paramagnetic behaviour for hydrated 2-Mn, 2-Co, 2-Ni, and 2-Cu. The value observed for $\mathbf{2}-\mathbf{M n} \cdot 14 \mathrm{H}_{2} \mathrm{O}$ fits well with the spin-only value for two octahedrally coordinated $\mathrm{Mn}^{2+}$ ions per formula unit in a high-spin configuration $(S=5)$, while for the other three compounds significantly larger values as compared to the respective spin-only values (for $S=3,2$, and 1 , respectively) were observed. This behaviour is typical for the late transition metals and can be attributed to an increased contribution of the orbit angular momentum $(L)$ to the magnetic moment. ${ }^{12}$ For $\mathbf{2}-\mathbf{F e} \cdot 4 \mathrm{H}_{2} \mathrm{O}$, the experimental value was considerably smaller than the respective spin-only value for two octahedrally coordinated high-spin $\mathrm{Fe}^{2+}$ ions $(S=4)$. Spincrossover effects including diamagnetic low-spin $\mathrm{Fe}^{2+}$ are estimated improbable as carboxylates and $\mathrm{H}_{2} \mathrm{O}$ are relatively weak ligands, ${ }^{13}$ and more likely, the decrease of the magnetic moment in $2-\mathrm{Fe} \cdot 4 \mathrm{H}_{2} \mathrm{O}$ could be due to an antiferromagnetic interaction between the $\mathrm{Fe}$ atoms. ${ }^{14}$ Presuming that the $\mathrm{Fe}$ atoms in the tetrahydrate of 2-Fe are linked directly by bridging carboxylate groups, a probable mechanism is the direct superexchange of the $\mathrm{Fe}^{2+}$ spins. ${ }^{15}$

Table 1. Isolation methods, isolated yields, decomposition temperatures, and magnetic moments of compounds $\mathrm{M}_{2}^{\prime}\left[\mathrm{Pt}(\mathrm{L})_{2}\right](2)$ in their isolated hydrates.

\begin{tabular}{|c|c|c|c|c|}
\hline Compound & Method & $\begin{array}{l}\text { Yield } \\
/ \% \\
\end{array}$ & $\begin{array}{l}T \text { (dec) } \\
/{ }^{\circ} \mathrm{C}\end{array}$ & $\begin{array}{l}\mu / \text { B.M. } \\
\text { (spin-only value) }\end{array}$ \\
\hline 2-Mg. $7 \mathrm{H}_{2} \mathrm{O}$ & A & 97 & 408 & \\
\hline 2-Ca.4 $4 \mathrm{H}_{2} \mathrm{O}$ & $\mathrm{B}$ & 79 & 430 & \\
\hline $2-\mathrm{Sr} \cdot 4 \mathrm{H}_{2} \mathrm{O}$ & B & 92 & 470 & \\
\hline 2-Ba. $2 \mathrm{H}_{2} \mathrm{O}$ & B & 94 & 430 & \\
\hline 2-Mn' $14 \mathrm{H}_{2} \mathrm{O}$ & A & 78 & 366 & $11.94(10.95 ; H S)$ \\
\hline 2-Fe $4 \mathrm{H}_{2} \mathrm{O}$ & A & 81 & 395 & $3.53(8.94 ; H S)$ \\
\hline 2- $\mathrm{Co} \cdot 4 \mathrm{H}_{2} \mathrm{O}$ & A & 93 & 337 & $8.36(6.93 ; H S)$ \\
\hline $2-\mathrm{Ni} \cdot 6 \mathrm{H}_{2} \mathrm{O}$ & A & 84 & 307 & $6.15(4.90)$ \\
\hline $2-\mathrm{Cu} \cdot 8 \mathrm{H}_{2} \mathrm{O}$ & B & 91 & 182 & $7.40(2.83)$ \\
\hline $2-\mathrm{Zn} \cdot 1 \mathrm{OH}_{2} \mathrm{O}^{9}$ & A & 91 & 398 & \\
\hline 2-Cd. $4 \mathrm{H}_{2} \mathrm{O}$ & $\mathrm{B}$ & 82 & 350 & \\
\hline
\end{tabular}

$\mathrm{A}=$ crystallization by layering the aqueous solution with acetone; $\mathrm{B}=$ precipitation from solution; $H S=$ high spin.

The IR spectra of compounds 2 containing transition metals display two or three strong $\mathrm{v}(\mathrm{C}=\mathrm{O})$ bands between 1590 and $1480 \mathrm{~cm}^{-1}$, which is significantly shifted to smaller wavenumbers as compared to the parent $\left[\mathrm{Pt}\left(\mathrm{H}_{2} \mathrm{~L}\right)\right](\mathbf{1} ; 1701$ and $1682 \mathrm{~cm}^{-1}$ ) and indicates therefore the full deprotonation of the carboxylic acid moieties. ${ }^{9}$ However, the spectra of some compounds (hydrated 2-Mg, 2-Ba, 2-Co, and 2-Cu) show additional bands above $1600 \mathrm{~cm}^{-1}$, which could be due to $\mathrm{COO} \cdots \mathrm{H}_{2} \mathrm{O}$ hydrogen bonding or varying carboxylate coordination modes. Generally, the $\mathrm{v}(\mathrm{C}=\mathrm{O})$ band pattern does not indicate the carboxylate coordination mode unambiguously, and there are no clear differences between metals favouring mono- or bidentate carboxylate coordination $(\mathrm{Mg}, \mathrm{Mn}-\mathrm{Zn})^{16-20}$ and those favouring highly bridging coordination modes ( $\mathrm{Ca}-\mathrm{Ba}, \mathrm{Cd}) .^{21-24}$ Moreover, the IR spectra do not necessarily reflect the binding situations in the crystal structures, as in the products the carboxylate coordination can change in the course of isolation as a result of crystal water loss. Solution NMR spectroscopy in $\mathrm{D}_{2} \mathrm{O}$ revealed the typical picture that has been previously observed with $\mathbf{2 - Z n} .{ }^{9}$ This comprises 
one ${ }^{1} \mathrm{H}$ NMR singlet signal at ca. $4.2 \mathrm{ppm}\left(\mathrm{CH}_{2}\right)$, which is broadened for 2-Ni due to moderate paramagnetism and not visible for 2-Mn, 2-Co, and 2-Cu (tentatively due to strong paramagnetism). For solubility reasons, a meaningful ${ }^{13} \mathrm{C} N M R$ spectrum could be observed only for the very soluble $\mathbf{2}-\mathbf{M g}$ displaying the typical set of signals for the $L$ ligand with identical chemical shifts as for $\mathbf{2 - Z n} .{ }^{9}$ A sharp ${ }^{195} \mathrm{Pt}$ NMR signal could be detected not only for 2-Mg (-3849 ppm), but also for the paramagnetic 2-Ni (-3841 ppm), both being very similar in their chemical shifts with $\mathbf{2}-\mathbf{Z n}(-3844 \mathrm{ppm})$. These ${ }^{13} \mathrm{C}$ and ${ }^{195} \mathrm{Pt}$ NMR data indicate that the $D_{2} \mathrm{O}$ solutions seem to contain predominantly solvent-separated $\left[\mathrm{Pt}(\mathrm{L})_{2}\right]^{4-}$ anions and hydrated $\mathrm{M}^{\prime 2+}$ cations.

\section{Solid-state molecular structures.}

In the course of this study, seven alkaline-earth and transition metal compounds with the $\left[\mathrm{Pt}(\mathrm{L})_{2}\right]^{4-}$ metalloligand could be structurally characterized by X-ray crystallography. Single crystals of the soluble compounds $\mathbf{2}$ were obtained similarly as for the previously reported $\mathbf{2}-\mathbf{Z n},{ }^{9}$ allowing acetone to diffuse slowly into the reaction solutions (2-Mg, 2-Co, 2-Ni), or directly from concentrated aqueous solutions (2-Mn, 2-Fe). For the less soluble $\mathbf{2}-\mathbf{S r}$ and $\mathbf{2}-\mathbf{C d}$, the preparation of single crystals suitable for X-ray diffraction was successful under hydrothermal conditions at $120{ }^{\circ} \mathrm{C}$. Under these conditions, 2-Ca and 2-Ba formed microcrystalline powders, and $\mathbf{2}-\mathrm{Cu}$, which precipitated in amorphous form at ambient temperature, decomposed to CuS at elevated temperature.

General information on the structures are summarized in Table 2 , and experimental details on the crystal structure determinations are given in Table S1. Less surprising, the Pt atom is always in a regular square-planar coordination by two dithiocarbamate groups with Pt-S bond lengths in a narrow range of 230.8(1)-232.5(1) pm. In most of the structures, the $\left[\mathrm{Pt}(\mathrm{L})_{2}\right]^{4-}$ metalloligand is symmetric with the $\mathrm{Pt}$ atom residing on a crystallographic centre of inversion, and only in 2$\mathrm{Mn} \cdot 16 \mathrm{H}_{2} \mathrm{O}$ the molecular symmetry is not crystallographically exposed. The divalent metal ions adopt their typical coordination numbers, ranging from six ( $\mathrm{Mg}, \mathrm{Mn}-\mathrm{Zn}$ ) to seven (Cd) and eight (Sr). The six-coordination is always close to an

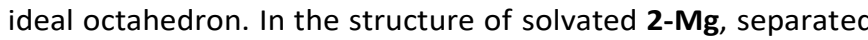

$\left[\mathrm{Mg}\left(\mathrm{H}_{2} \mathrm{O}\right)_{6}\right]^{2+}$ and $\left[\mathrm{Pt}(\mathrm{L})_{2}\right]^{4-}$ ions are present, and therefore this compound is formally a "zero-dimensional" coordination polymer (Figure 1). Consequently, the bonding situation of the $\mathrm{Mg}^{2+}$ ions is different from that in $\mathrm{Mg}(\mathrm{OAc})_{2}\left(\mathrm{H}_{2} \mathrm{O}\right)_{4}$, comprising $\mathrm{KO}$-monodentate coordination of the carboxylate groups in a trans-arrangement. ${ }^{16}$ However, magnesium carboxylates with fully hydrated $\mathrm{Mg}^{2+}$ ions and non-coordinated carboxylate anions are also known, e.g. the fumarate ${ }^{25}$ and hydrogen 2,3di(tert-butyl)succinate. ${ }^{26}$<smiles>O=C([O-])CN(CC(=O)O)C1=[SH][Pb]2(S1)SC(N(CC(=O)[O-])CC(=O)[O-])S2</smiles>

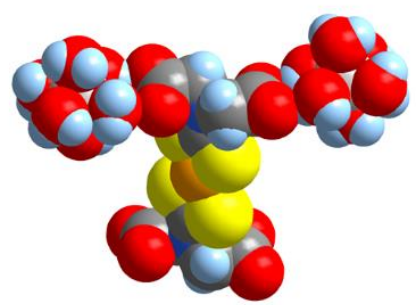

Figure 1. Schematic representation of the molecular connectivity in $\mathbf{2}-\mathbf{M g} \cdot \mathbf{2 1 . 5} \mathrm{H}_{2} \mathrm{O} \cdot$ acetone (left), and the resulting molecular architecture in the crystal (space-filling model; right). Non-coordinated solvent of crystallization omitted for clarity.

In all other cases, the oxophilic metal atoms are coordinated by two or more carboxylate groups and coordinatively saturated

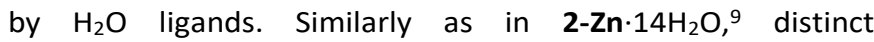
$\mathrm{M}$ (carboxylate) $)_{2}\left(\mathrm{H}_{2} \mathrm{O}\right)_{4}$ units are present in the solid-state structures of hydrated 2-Mn, 2-Fe, 2-Co, and 2-Ni. In the latter two compounds, the carboxylate groups are $\mathrm{KO}$-coordinated in a trans-arrangement, and the coordinative environment of the metal atoms is therefore identical as in the corresponding hydrated acetates, $\mathrm{M}^{\prime}(\mathrm{OAc})_{2}\left(\mathrm{H}_{2} \mathrm{O}\right)_{4}\left(\mathrm{M}^{\prime}=\mathrm{Co} ;{ }^{18} \mathrm{M}^{\prime}=\mathrm{Ni}^{19}\right)$. By contrast, a cis-coordination was observed for hydrated 2-Mn and 2-Fe, which has been seen previously with hydrated $\mathbf{2}-\mathbf{Z n} .^{9}$ All four carboxylate groups of the $\left[\mathrm{Pt}(\mathrm{L})_{2}\right]^{4-}$ metalloligand are in a $\mathrm{k} O$-monodentate mode for the iron and zinc compounds, while the connectivity pattern is more divers in the manganese derivative. Herein, only two out of four $\mathrm{COO}^{-}$groups are $\mathrm{kO}-$

Table 2. General parameters for the solid-state structures of solvated compounds $\mathrm{M}_{2}{ }_{2}\left[\mathrm{Pt}(\mathrm{L})_{2}\right](\mathbf{2})$, as determined by single-crystal $\mathrm{X}$-ray diffraction.

\begin{tabular}{|c|c|c|c|c|}
\hline & $r\left(\mathrm{M}^{\prime 2+}\right) / \mathrm{pm}^{a 27}$ & $\begin{array}{l}\text { carboxylate }+\mathrm{H}_{2} \mathrm{O} \\
\text { coord. bonds at } \mathrm{M}^{\prime}\end{array}$ & carboxylate coordination & CP dimension \\
\hline 2-Mg. $21.5 \mathrm{H}_{2} \mathrm{O} \cdot$ acetone & 86 & $0+6$ & non-coordinated & 0 \\
\hline $2-\mathrm{Sr} \cdot 4 \mathrm{H}_{2} \mathrm{O}$ & 132 & $6+2$ & $\mathrm{~K} O: \mathrm{K}^{2} O, O^{\prime}: \mathrm{K} O^{\prime} ; \mathrm{K} O: \mathrm{K} O^{\prime}($ syn) & 3 \\
\hline 2-Mn'16 $\mathrm{H}_{2} \mathrm{O}$ & $97(H S)$ & $2(c i s)+4$ & $\mathrm{\kappa} O: \mathrm{K} O^{\prime}($ anti); $\mathrm{\kappa} O$; non-coordinated & 1 \\
\hline 2-Fe $\cdot 14 \mathrm{H}_{2} \mathrm{O}$ & $92(H S)$ & $2(c i s)+4$ & $\mathrm{k} O$ & 2 \\
\hline 2-Co $22 \mathrm{H}_{2} \mathrm{O}$ & $88.5(H S)$ & 2 (trans) +4 & $\mathrm{\kappa} O$ & 2 \\
\hline $2-\mathrm{Ni} \cdot 23.5 \mathrm{H}_{2} \mathrm{O}$ & 83 & $2($ trans $)+4$ & $\mathrm{kO}$ & 2 \\
\hline $2-\mathrm{Zn} \cdot 14 \mathrm{H}_{2} \mathrm{O}^{9}$ & 88 & $2(c i s)+4$ & $\mathrm{k} O$ & 2 \\
\hline $2-\mathrm{Cd} \cdot 4 \mathrm{H}_{2} \mathrm{O}$ & 109 & $5+2$ & $\mathrm{~K} O: \mathrm{K}^{2} O, O^{\prime}: \mathrm{K} O^{\prime} ; \mathrm{K} O$ & 2 \\
\hline
\end{tabular}

${ }^{a}$ Values for hexa-coordinated ions; $H S=$ high spin 
coordinated, while one is not coordinated to $\mathrm{Mn}$ and one adopts а $\mathrm{\kappa} O: \mathrm{kO}^{\prime}$-bridging mode (Figure 2). A rather complex carboxylate coordination has also been observed in polymeric $\mathrm{Mn}(\mathrm{OAC})_{2}\left(\mathrm{H}_{2} \mathrm{O}\right)_{4}$ ( $\mathrm{KO}: \mathrm{KO}$ - and $\mathrm{KO}: \mathrm{KO}^{\prime}$-bridging groups), ${ }^{17}$ while $\mathrm{Zn}(\mathrm{OAC})_{2}\left(\mathrm{H}_{2} \mathrm{O}\right)_{4}$ contains monomeric units with trans-arranged, $\mathrm{K}^{2} \mathrm{O}, \mathrm{O}^{\prime}$-chelating acetate ligands. ${ }^{20}$ The solid-state structure of any hydrated form of iron(II) acetate is not known to the best of our knowledge.
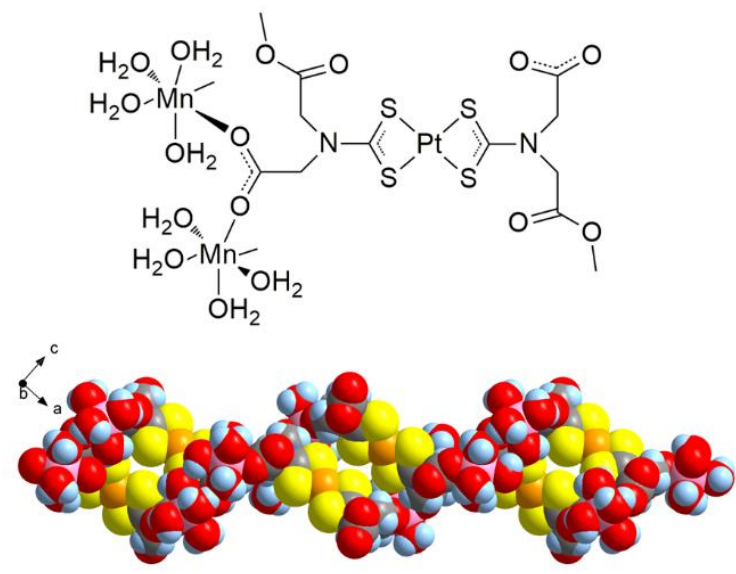

Figure 2. Schematic representation of the molecular connectivity in $\mathbf{2}-\mathbf{M n} \cdot 16 \mathrm{H}_{2} \mathrm{O}$ (above), and the resulting polymeric ribbon structure in the crystal (below; space-filling model). Non-coordinated crystal water omitted for clarity. The 1D polymeric structure extends perpendicularly to $\left(\begin{array}{lll}5 & 0 & 4\end{array}\right)$.

As a result of the low-symmetric connectivity between $\mathrm{Mn}^{2+}$ ions and $\left[\mathrm{Pt}(\mathrm{L})_{2}\right]^{4-}$ metalloligands in $2-\mathrm{Mn} \cdot 16 \mathrm{H}_{2} \mathrm{O}$, a unique twostranded ribbon structure is formed, that is, the polymeric structure extends in only one dimension. By contrast, the hydrated forms of 2-Fe, 2-Co and 2-Ni form two-dimensional polymeric structures in the solid state. $2-\mathrm{Fe} \cdot 14 \mathrm{H}_{2} \mathrm{O}$ is isotypic with $\mathbf{2 - Z n} \cdot 14 \mathrm{H}_{2} \mathrm{O}^{9}$ and exists as corrugated layers with relatively small pores (Figure 3 ). These vacancies are occupied by additional water of crystallization, which could be localized in the course of $\mathrm{X}$-ray structure refinement as it is fixed by hydrogen bonding in a defined manner. However, this crystal water could not be removed without destruction of the structure, and drying of the crystals always led to decomposition into crystallographically inconsistent powder. The isotypic crystal structures of hydrated 2-Co and 2-Ni also contain two-dimensional polymeric arrays. As a result of the $180^{\circ}$ coordination angle between the two carboxylate groups at the $3 \mathrm{~d}$ metal, these layers are entirely plain and much less dense than in the iron and zinc derivatives (Figure 4). The vacancies are filled with large amounts of diffuse solvent of crystallization and the structures are destroyed quite readily upon isolation of the crystals from their mother solutions.

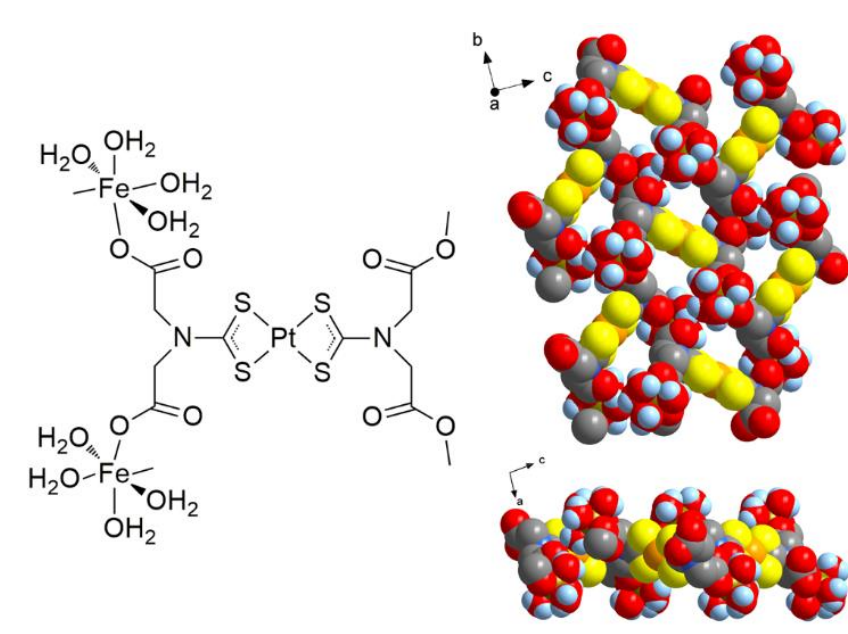

Figure 3. Schematic representation of the molecular connectivity in 2-Fe $14 \mathrm{H}_{2} \mathrm{O}$ (left), and the resulting layer structure in the crystal (right; space-filling model; viewed in projections on and along the layer). Non-coordinated crystal water omitted for clarity. The 2D polymeric structure extends parallel to $\left(\begin{array}{lll}1 & 0 & 0\end{array}\right)$. The crystal structure of $2-\mathbf{z n} \cdot 14 \mathrm{H}_{2} \mathrm{O}^{9}$ is isotypic.

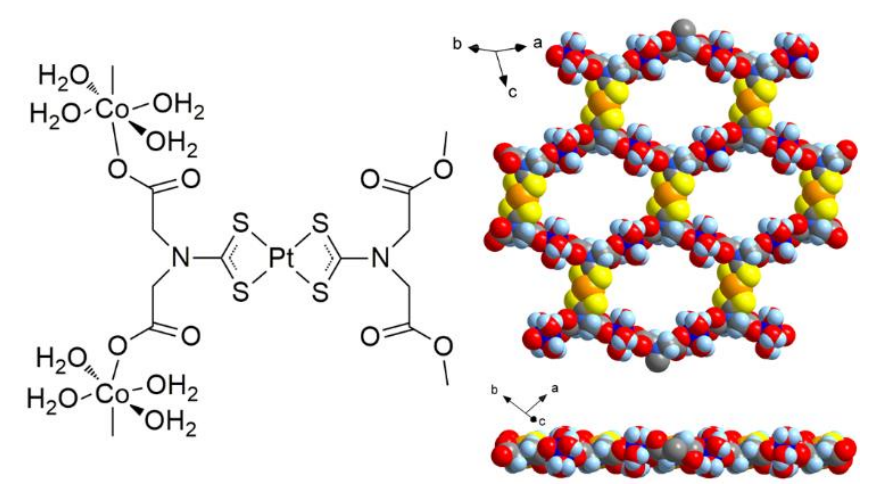

Figure 4. Schematic representation of the molecular connectivity in $\mathbf{2}-\mathbf{C o} \cdot 22 \mathrm{H}_{2} \mathrm{O}$ (left), and the resulting layer structure in the crystal (right; space-filling model; viewed in projections on and along the layer). Non-coordinated crystal water omitted for clarity. The 2D polymeric structure extends parallel to $\left(\begin{array}{lll}1 & 2 & -1\end{array}\right)$. The crystal structure of $\mathbf{2}-\mathbf{N i} \cdot 23.5 \mathrm{H}_{2} \mathrm{O}$ is isotypic.

While the metal ionic radii of the first-row transition metals cover a relatively small range, the ions $\mathrm{Cd}^{2+}$ and $\mathrm{Sr}^{2+}$ are significantly larger (cf. Table 2). This circumstance is reflected in the solid-state structures of $\mathbf{2}-\mathbf{C d} \cdot 4 \mathrm{H}_{2} \mathrm{O}$ and $\mathbf{2}-\mathbf{S r} \cdot 4 \mathrm{H}_{2} \mathrm{O}$, in which the $\mathrm{M}^{\prime 2+}$ centers adopt coordination numbers larger than six. Moreover, for the large closed-shell ions $\mathrm{Cd}^{2+}$ and $\mathrm{Sr}^{2+}$ electrostatic attraction between the metal ions and carboxylic groups is more important than covalent bonding, thus resulting in an increased number of $\mathrm{M}^{\prime}$-carboxylate bonds together with a reduced number of $\mathrm{H}_{2} \mathrm{O}$ ligands, and the formation of less defined coordination polyhedra. ${ }^{28}$ In hydrated 2-Cd, the cadmium centers are coordinated by five carboxylate oxygen 
atoms (Cd-O 228.2(2)-248.0(2) pm) and two $\mathrm{H}_{2} \mathrm{O}$ ligands (Cd-O 227.1(2) pm both) in a somewhat pentagonal-bipyramidal fashion, in which the $\mathrm{H}_{2} \mathrm{O}$ ligands define formally the axial positions $\left(\mathrm{H}_{2} \mathrm{O}-\mathrm{Cd}-\mathrm{OH}_{2}=163.86(8)^{\circ}\right.$; Figure 5). The five $\mathrm{Cd}$ carboxylate bonds arise from a highly bridging $\mathrm{k} O: \mathrm{K}^{2} \mathrm{O}, \mathrm{O}^{\prime}: \mathrm{K} \mathrm{O}^{\prime}-$ tetradentate coordination of one $\mathrm{COO}^{-}$group and a common $\mathrm{KO}$-monodentate coordination of another $\mathrm{COO}^{-}$group. As a result of this connectivity pattern, a very dense twodimensional polymeric structure is formed, which does not contain significant voids accessible for additional solvent. It is therefore less surprising that the crystals do not decompose upon drying and the isolated powdery product is crystallographically identical with the single crystals used for structure elucidation. A rather irregular seven-coordination of cadmium formed by five Cd-O(carboxylate) (229.4(4)-259.7(3) $\mathrm{pm}$ ) and two $\mathrm{Cd}-\mathrm{OH}_{2}(229.9(3)$ and 232.5(4) pm) bonds has also been reported for $\mathrm{Cd}(\mathrm{OAc})_{2}\left(\mathrm{H}_{2} \mathrm{O}\right)_{2} .{ }^{24}$ Through $\mathrm{k}^{2} \mathrm{O}, \mathrm{O}^{\prime}$-chelating and $\mathrm{K}^{2} \mathrm{O}, \mathrm{O}^{\prime}: O$-bridging coordination of the two acetate units, this compound exhibits a one-dimensional polymeric structure in the solid state.

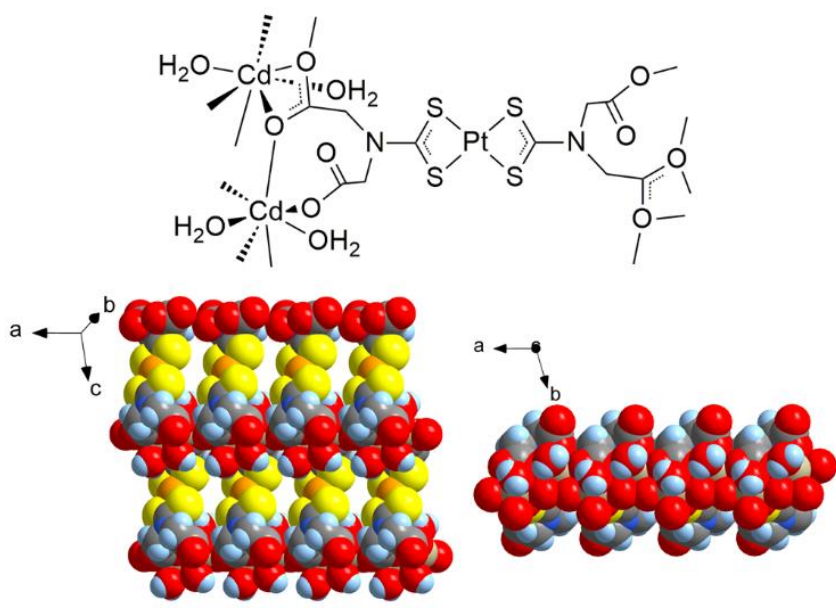

Figure 5. Schematic representation of the molecular connectivity in 2-Cd.4 $\mathrm{H}_{2} \mathrm{O}$ (above), and the resulting layer structure in the crystal (below; space-filling model; viewed in projections on and along the layer). The $2 \mathrm{D}$ polymeric structure extends parallel to $\left(\begin{array}{lll}0 & 1 & 0\end{array}\right)$.

The crystal structure of $\mathbf{2 - S r} \cdot 4 \mathrm{H}_{2} \mathrm{O}$ shows some similarities to that of $2-\mathrm{Cd} \cdot 4 \mathrm{H}_{2} \mathrm{O}$, with the exception that the $\mathrm{KO}$-monodentate carboxylate coordination is extended to a $\mathrm{kO}: \mathrm{k} O^{\prime}$-bridging coordination (Figure 6). As a result, the strontium atom adopts an irregular eight-coordination by six carboxylate oxygen atoms (Sr-O 248(1)-268(1) pm) and two $\mathrm{H}_{2} \mathrm{O}$ ligands (Sr-O 257(1) and 261(1) pm), and the additional Sr-carboxylate linkage leads to extension of the polymeric structure in the third dimension. Similar as for $2-\mathrm{Cd} \cdot 4 \mathrm{H}_{2} \mathrm{O}$, the packing of the $\mathrm{M}^{\prime 2+}$ and $\left[\mathrm{Pt}(\mathrm{L})_{2}\right]^{4-}$ units is very compact and does not allow for the inclusion of additional water of crystallization. This explains why the crystals of the strontium derivative are stable against dehydration and why the isolated powder is crystallographically identical with the structurally analyzed single crystals. From the related strontium acetate, the acetic acid solvate $\mathrm{Sr}(\mathrm{OAc})_{2} \cdot 2 \mathrm{H}_{2} \mathrm{O} \cdot \mathrm{HOAC}$ has been structurally characterized in the solid state, revealing a close polymeric network structure with eight-coordinated $\mathrm{Sr}$ atoms as well. ${ }^{22}$

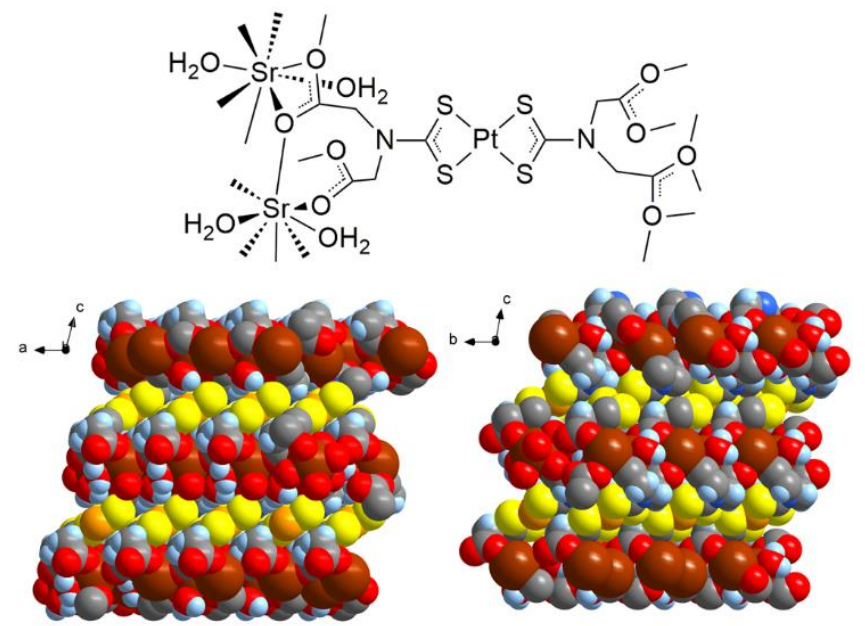

Figure 6. Schematic representation of the molecular connectivity in $\mathbf{2 - S r} \cdot 4 \mathrm{H}_{2} \mathrm{O}$ (above), and the resulting $3 \mathrm{D}$ polymeric structure in the crystal (below; space-filling model; viewed in projections on (lllll) and $\left.\left(\begin{array}{lll}1 & 0 & 0\end{array}\right)\right)$.

\section{Conclusions}

Summarizing the results reported here, we prepared ten new heterobimetallic dithiocarbamatocarboxylates (DTCCs) of the general type $\mathrm{M}^{\prime}{ }_{2}\left[\mathrm{Pt}(\mathrm{L})_{2}\right]\left(\mathrm{L}=\left\{\mathrm{SSC}-\mathrm{N}\left(\mathrm{CH}_{2} \mathrm{COO}\right)_{2}\right\}^{3-}\right)$, where $\mathrm{M}^{\prime}$ is an alkaline-earth or divalent transition metal. The very good isolated yields of pure products demonstrated again the high stability of the $\left[\mathrm{Pt}(\mathrm{L})_{2}\right]^{4-}$ metalloligand against metal exchange at the dithiocarbamate group. Thus, the preparations proceeded in a deliberate manner also for rather thiophilic $\mathrm{M}^{\prime 2+}$ ions such as $\mathrm{Cd}^{2+}$, of which numerous dithiocarbamate complexes are described in the previous literature. ${ }^{11,29-31}$ This is also true for "ambiphilic" metal ions such as $\mathrm{Ni}^{2+}$ and $\mathrm{Cu}^{2+}$, of which dithiocarbamate complexes with the $\mathrm{L}^{3-}$ ligand have been reported by Leka et al. ${ }^{32}$ and by us. ${ }^{10}$ It will be a subject of future investigations if comparable $\mathrm{M}^{\prime}{ }_{2}\left[\mathrm{M}(\mathrm{L})_{2}\right]$ complexes are also accessible when platinum is replaced by divalent palladium or nickel. Structural characterization of several products in the course of this study revealed that the oxophilic metal $\mathrm{M}^{\prime}$ exerts a stronger impact on the solid-state structure than the thiophilic metal $\mathrm{M}$ does. While $\mathrm{Zn}_{2}\left[\mathrm{M}(\mathrm{L})_{2}\right](\mathrm{M}=\mathrm{Ni}, \mathrm{Pd} \mathrm{Pt})$ have been shown to form isotypic two-dimensional structures, ${ }^{9,10}$ the here reported $\mathrm{M}_{2}{ }_{2}\left[\mathrm{Pt}(\mathrm{L})_{2}\right]$ compounds $\left(\mathrm{M}^{\prime}=\mathrm{Mg}-\mathrm{Ba}, \mathrm{Mn}-\mathrm{Cu}, \mathrm{Cd}\right)$ show a broad variety of zero- to three-dimensional architectures. For closed-shell ions such as the alkaline earths and cadmium, CPs of higher dimensionality seem to be increasingly favoured with increasing metal ion radius, which is due to rising coordination numbers and an increasing tendency towards bridging carboxylate coordination patterns together with lower degrees of hydration. A less clear trend was observed within the first-row transition metal series, where the structures are governed by the presence of distinct coordination octahedrons around the $\mathrm{M}^{\prime}$ atoms, including 
cis/trans isomerism of $\mathrm{M}^{\prime}(\text { carboxylate })_{2}\left(\mathrm{H}_{2} \mathrm{O}\right)_{4}$ motifs. Generally, the coordination of the $\mathrm{M}^{\prime 2+}$ ions by the carboxylate units is often similar as in the related acetates, but concrete predictions are difficult. Regarding the structural diversity of the $\mathrm{M}_{2}{ }_{2}\left[\mathrm{Pt}(\mathrm{L})_{2}\right]$, it is less surprising that the solubilities and thermal stabilities cover much wider ranges as it has been previously seen with $\mathrm{Zn}_{2}\left[\mathrm{M}(\mathrm{L})_{2}\right](\mathrm{M}=\mathrm{Ni}, \mathrm{Pd} \mathrm{Pt}) .{ }^{9,10}$ While the transitionmetal containing CPs are potentially useful in catalysis or as precursors for heterobimetallic oxides or sulfides, the heavier alkaline-earth derivatives could be doped with lanthanide ions in order to obtain materials with interesting optic or magnetic properties.

\section{Experimental}

General. Unless otherwise noted, all operations were performed under atmospheric conditions without exclusion of air. All starting materials and solvents were obtained from commercial suppliers and used without further purification. $\left[\mathrm{Pt}\left(\mathrm{H}_{2} \mathrm{~L}\right)_{2}\right]$ (1) was prepared from $\mathrm{K}_{3}(\mathrm{~L})$ as described previously. ${ }^{9} \mathrm{NMR}$ spectra were recorded on a Bruker AVIII 400 machine $\left(5 \mathrm{~mm} \mathrm{BBO} ;{ }^{1} \mathrm{H}\right.$ : $400.1 \mathrm{MHz},{ }^{13} \mathrm{C}$ : $100.6 \mathrm{MHz},{ }^{195} \mathrm{Pt}$ : $86.0 \mathrm{MHz}$ ) at $295(2) \mathrm{K}$. Chemical shifts are referenced internally to the solvent $H D O$ signal $\left({ }^{1} \mathrm{H} ; \delta=4.79 \mathrm{ppm}\right)$, externally to neat tetramethylsilane $\left({ }^{13} \mathrm{C} ; \delta=0 \mathrm{ppm}\right)$, or externally to $1.2 \mathrm{~mol} / \mathrm{L} \mathrm{Na} 2\left[\mathrm{PtCl}_{6}\right]$ in $\mathrm{D}_{2} \mathrm{O}$ $\left({ }^{195} \mathrm{Pt} ; \delta=0 \mathrm{ppm}\right)$. IR spectra were measured on a Bruker Vertex V70 FTIR spectrometer equipped with a diamond ATR unit, and elemental analyses $(\mathrm{C}, \mathrm{H}, \mathrm{N}, \mathrm{S})$ were performed using a VARIO EL cube. The magnetic moments were determined by the Gouy method at $293 \mathrm{~K}$, using the magnetic balance Johnson Matthey MSB MK I. ${ }^{12}$ Diamagnetic corrections have been applied as $\chi_{\mathrm{mol}, \mathrm{corr}}=\chi_{\mathrm{mol}}-2 \chi_{\mathrm{mol}, \mathrm{L}, \mathrm{dia}}-2 \chi_{\mathrm{mol}, \mathrm{M}^{\prime}, \mathrm{dia}}-\chi_{\mathrm{mol}, \mathrm{Pt}, \mathrm{dia}}-n \chi_{\mathrm{mol}, \mathrm{H} 2 \mathrm{O}, \mathrm{dia}}$. The molar diamagnetic susceptibility of the $\mathrm{L}^{3-}$ ligand has been calculated using increment values from literature as $\chi_{\text {mol, L, dia }}=-$ $9.57 \cdot 10^{-5} \mathrm{emu} / \mathrm{mol}$, and the values for the metal ions were taken from the literature as $\chi_{\mathrm{mol}, \mathrm{Pt}, \mathrm{dia}}=-3.9 \cdot 10^{-5} \mathrm{emu} / \mathrm{mol}, \chi_{\mathrm{mol}, \mathrm{Mn}, \mathrm{dia}}=$ $-1.4 \cdot 10^{-5} \mathrm{emu} / \mathrm{mol}, \chi_{\mathrm{mol}, \mathrm{Fe}, \mathrm{dia}}=-1.3 \cdot 10^{-5} \mathrm{emu} / \mathrm{mol}, \chi_{\mathrm{mol}, \mathrm{Co}, \mathrm{dia}}=-$ $1.2 \cdot 10^{-5} \mathrm{emu} / \mathrm{mol}, \chi_{\mathrm{mol}, \mathrm{Ni}, \mathrm{dia}}=-1 \cdot 1 \cdot 10^{-5} \mathrm{emu} / \mathrm{mol}, \chi_{\mathrm{mol}, \mathrm{Cu}, \mathrm{dia}}=-$ $1.1 \cdot 10^{-5} \mathrm{emu} / \mathrm{mol} .{ }^{33}$ The single-crystal X-ray intensity data were collected on a STOE IPDS $2 \mathrm{~T}$ diffractometer equipped with a $34 \mathrm{~cm}$ image-plate detector, using Mo-Ka radiation, at $T=133(2)$ K. The crystal structures were solved with SHELXT-2018/334 and refined by full matrix least-squares methods on $F^{2}$ using SHELXL2018/3,35 using the Olex 1.2 environment. ${ }^{36}$ Numerical absorption correction was applied to the intensity data. ${ }^{37}$ Where applicable, diffuse solvent electron density was considered using the "solvent mask" tool integrated in Olex 1.2. ${ }^{36}$ The so-obtained amounts of disordered water molecules per formula unit were determined as 9.5 (2-Mg), 7.0 (2-Mn), 10.0 (2-Co), and 11.5 (2- $\mathrm{Ni}$; round to $0.5 \mathrm{H}_{2} \mathrm{O}$ units each). Simultaneous TG/DTA investigations were carried out on a Netzsch STA 449F5 thermo balance. Therefore, ca. $2 \mathrm{mg}$ of each sample were placed in an $\mathrm{Al}_{2} \mathrm{O}_{3}$ crucible, applying a gas flow of
$50 \mathrm{~mL} / \mathrm{min} \mathrm{N}_{2}$ and a heating rate of $10 \mathrm{~K} / \mathrm{min}$ during measurement.

Synthesis of compounds $\mathrm{M}_{2}\left[\mathrm{Pt}(\mathrm{L})_{2}\right]$ (2; general procedure for soluble products). Similar as previously described for the related $\mathrm{Zn}_{2}\left[\mathrm{Pt}(\mathrm{L})_{2}\right](2-\mathrm{Zn}),{ }^{9}$ a mixture of $\left[\mathrm{Pt}\left(\mathrm{H}_{2} \mathrm{~L}\right)_{2}\right] \cdot 0.5 \mathrm{H}_{2} \mathrm{O}\left(\mathbf{1} \cdot 0.5 \mathrm{H}_{2} \mathrm{O} ; 0.31\right.$ $\mathrm{g}, 0.5 \mathrm{mmol}$ ) and the respective metal acetate $(2.0-3.0 \mathrm{mmol}$, 4-6 Equiv.) in $40 \mathrm{ml}$ water was stirred at ambient temperature until the precursor complex has completely dissolved (30-60 $\mathrm{min}$ ). The solution was filtered if necessary, then carefully layered with acetone until the mixture became turbid (ca. 30 $\mathrm{ml}$ ), and allowed to stand for few days. The crystallized product was isolated by vacuum filtration, washed with ethanol and acetone and dried at $40{ }^{\circ} \mathrm{C}$ overnight. The so-obtained microcrystalline powders are poorly to moderately soluble in water and insoluble in most organic solvents.

2-Mg. $7 \mathrm{H}_{2} \mathrm{O}$ : From $\mathrm{Mg}(\mathrm{OAc})_{2} \cdot 4 \mathrm{H}_{2} \mathrm{O}$ (0.64 g, $3.0 \mathrm{mmol}, 6$ Equiv.). Layering the aqueous solution with acetone afforded large, plate-like, yellow crystals. Yield: $0.38 \mathrm{~g}(97 \%)$. Dec. $408^{\circ} \mathrm{C}$. Anal. calcd. for $\mathrm{C}_{10} \mathrm{H}_{22} \mathrm{Mg}_{2} \mathrm{~N}_{2} \mathrm{O}_{15} \mathrm{PtS}_{4}\left(M=782.24 \mathrm{~g} \mathrm{~mol}^{-1}\right): \mathrm{C} 15.35, \mathrm{H}$ 2.82, N 3.58, S 16.40 \%; found: C 15.35, H 2.82, N 3.55, S 16.43 \%. ${ }^{1} \mathrm{H}$ NMR: $\delta 4.16$ (s; $\left.\mathrm{CH}_{2}\right)$ ppm. ${ }^{13} \mathrm{C}$ NMR: $53.6\left(\mathrm{CH}_{2}\right), 173.5$ (COO), 211.6 (CSS) ppm. ${ }^{195} \mathrm{Pt}$ NMR: -3849 (s) ppm. IR: v 3495(sh br), 3291(m br), 3101(sh br), 2991(sh br), 1694(m), 1588(s), 1512(s), 1513(s), 1426(m), 1392(s), 1306(s), 1235(s), 1171(m), 1090(w), 1030(m), 1004(w), 955(m), 905(m br), 735(s br), 635(m br), 619(s br), 603(s), 543(s br), 353(s) cm-1. Single crystals of $\mathbf{2}-\mathbf{M g} \cdot 21.5 \mathrm{H}_{2} \mathrm{O} \cdot$ acetone suitable for $\mathrm{X}$-ray structure determination were obtained directly from the acetone/water mixture prior to isolation of the product.

2-Mn-14 $\mathrm{H}_{2} \mathrm{O}$ : From $\mathrm{Mn}(\mathrm{OAc})_{2} \cdot 4 \mathrm{H}_{2} \mathrm{O}$ (0.74 g, $3.0 \mathrm{mmol}, 6$ Equiv.). Layering the aqueous solution with acetone led to the formation of a small amount of an amorphous, brown precipitate, which was filtered off. The resulting clear solution was allowed to evaporate slowly to a total volume of ca. $10 \mathrm{ml}$, affording large, yellow-brown, block-like crystals of the desired product. Yield: $0.39 \mathrm{~g}$ (78\%). Dec. $366^{\circ} \mathrm{C}$. Anal. calcd. for $\mathrm{C}_{10} \mathrm{H}_{36} \mathrm{Mn}_{2} \mathrm{~N}_{2} \mathrm{O}_{22} \mathrm{PtS}_{4}\left(M=969.61 \mathrm{~g} \mathrm{~mol}^{-1}\right): \mathrm{C} 12.39, \mathrm{H} 3.74, \mathrm{~N}$ 2.89, S $13.23 \%$; found: C 12.40, H 3.75, N 2.86, S $13.26 \%$. Meaningful NMR data could not be obtained due to the paramagnetic nature of the compound. IR: v 3322(m br), 2976(w), 2936(w), 1580(s), 1499(s), 1425(m), 1386(s), 1307(s), 1249(w), 1228(s), 1175(m), 1026(m), 1004(w), 952(m), 910(m), 716(s br), 636(m), 602(s), 560(w), 540(s br), 391(w), 356(s), $220(\mathrm{~s}), 212(\mathrm{~s}) \mathrm{cm}^{-1}$. Single crystals of $2-\mathbf{M n} \cdot 16 \mathrm{H}_{2} \mathrm{O}$ suitable for $\mathrm{X}$-ray structure determination were obtained directly from the aqueous solution prior to isolation of the product.

2-Co. $4 \mathrm{H}_{2} \mathrm{O}$ : From $\mathrm{Co}(\mathrm{OAc})_{2} \cdot 4 \mathrm{H}_{2} \mathrm{O}(0.50 \mathrm{~g}, 2.0 \mathrm{mmol}, 4$ Equiv. $)$. A pale orange, crystalline precipitate deposited from the acetone/water mixture within few days, which turned into brick red powder upon isolation. Yield: $0.37 \mathrm{~g}$ (93\%). Dec. $337{ }^{\circ} \mathrm{C}$. Anal. calcd. for $\mathrm{C}_{10} \mathrm{H}_{16} \mathrm{Co}_{2} \mathrm{~N}_{2} \mathrm{O}_{12} \mathrm{PtS}_{4}\left(M=797.45 \mathrm{~g} \mathrm{~mol}^{-1}\right)$ : $\mathrm{C}$ 15.06, H 2.02, N 3.51, S 16.08 \%; found: C 15.07, H 2.06, N 3.52, S $16.09 \%$. Meaningful NMR data could not be obtained due to 
the paramagnetic nature of the compound. IR: $v$ 3267(m br) 2990(w), 2921(w), 1691(m), 1589(s), 1498(s), 1423(m), 1391(s) 1299(s), 1222(s), 1184(s), 1089(w), 1023(m), 1007(w), 952(m), 902(m), 730(s), 710(s), 638(s), 616(s), 605(m), 561(s), 540(s), 394(m br), 356(s), 275(m br), 260(s br) cm-1. Single crystals of 2$\mathrm{Co} \cdot 22 \mathrm{H}_{2} \mathrm{O}$ suitable for X-ray structure determination were obtained directly from the acetone/water solution prior to isolation of the product.

2- $\mathrm{Ni} \cdot 6 \mathrm{H}_{2} \mathrm{O}$ : From $\mathrm{Ni}(\mathrm{OAc})_{2} \cdot 4 \mathrm{H}_{2} \mathrm{O}(0.75 \mathrm{~g}, 3.0 \mathrm{mmol}, 6$ Equiv. $)$. A pale green, crystalline precipitate deposited from the acetone/water mixture within few days, which turned into bright yellow-green powder upon isolation. Yield: $0.35 \mathrm{~g}(84 \%)$. Dec. $307^{\circ} \mathrm{C}$. Anal. calcd. for $\mathrm{C}_{10} \mathrm{H}_{20} \mathrm{~N}_{2} \mathrm{Ni}_{2} \mathrm{O}_{14} \mathrm{PtS}_{4}(M=833.00 \mathrm{~g}$ $\mathrm{mol}^{-1}$ ): $\mathrm{C} 14.42, \mathrm{H} 2.42, \mathrm{~N} 3.36, \mathrm{~S} 15.40 \%$; found: C 14.43, H 2.46, N 3.38, S $15.45 \% .{ }^{1} \mathrm{H}$ NMR: $\delta 4.18$ (s br; $\mathrm{CH}_{2}$ ) ppm. ${ }^{195} \mathrm{Pt}$ NMR: 3841 ppm. IR: v 3210(m br), 2979(w), 1571(s), 1508(s), 1422(m), 1385(s), 1309(s), 1235(s), 1172(m), 1025(m), 998(w), 951(m), 890(m br), 737(s), 643(m br), 625(s), 616(s), 612(s), 602(s), 548(s), 358(s), 263(m br), 255(m), 249(m), 203(s) $\mathrm{cm}^{-1}$. Single

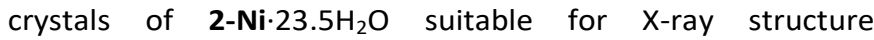
determination were obtained directly from the acetone/water solution prior to isolation of the product.

Synthesis of compounds $\mathrm{M}_{2}\left[\mathrm{Pt}(\mathrm{L})_{2}\right]$ (2; general procedure for poorly soluble products). A mixture of $\left[\mathrm{Pt}\left(\mathrm{H}_{2} \mathrm{~L}\right)_{2}\right] \cdot 0.5 \mathrm{H}_{2} \mathrm{O}\left(\mathbf{1} \cdot 0.5 \mathrm{H}_{2} \mathrm{O} ; 0.31\right.$ $\mathrm{g}, 0.5 \mathrm{mmol}$ ) and the respective metal acetate $(2.0-3.0 \mathrm{mmol}$ 4-6 Equiv.) in $60 \mathrm{ml}$ water was heated to reflux for $30 \mathrm{~min}$. After the mixture was allowed to cool to ambient temperature, the precipitated product was isolated by vacuum filtration, washed with water and dried at $40{ }^{\circ} \mathrm{C}$ overnight. The so-obtained microcrystalline powders are almost insoluble in water.

2-Ca. $4 \mathrm{H}_{2} \mathrm{O}$ : From $\mathrm{Ca}(\mathrm{OAc})_{2} \cdot 2 \mathrm{H}_{2} \mathrm{O}(0.39 \mathrm{~g}, 2.0 \mathrm{mmol}, 4$ Equiv.). The product precipitated as yellow, microcrystalline powder. Yield: $0.30 \mathrm{~g}$ (79\%). Dec. $430{ }^{\circ} \mathrm{C}$. Anal. calcd. for $\mathrm{C}_{10} \mathrm{H}_{16} \mathrm{Ca}_{2} \mathrm{~N}_{2} \mathrm{O}_{12} \mathrm{PtS}_{4}\left(M=759.74 \mathrm{~g} \mathrm{~mol}^{-1}\right): \mathrm{C} 15.81, \mathrm{H} 2.12, \mathrm{~N}$ 3.69, S $16.88 \%$; found: C 15.82, H 2.15, N 3.68, S $16.85 \%$. ${ }^{1} \mathrm{H}$ NMR: $\delta 4.13$ (s; $\mathrm{CH}_{2}$ ) ppm. IR: v 3526(w br), 3447(w br), 3395(w br), 3121(w br), 2922(w), 1585(s), 1508(s), 1445(s), 1422(m), 1400(m), 1389(s), 1323(s), 1302(s), 1282(m), 1240(s), 1169(m), 1026(m), 997(w), 947(m), 916(s), 753(m br), 719(s), 640(m), 614(s), 597(m br), 561(s), 520(s), 442(m), 402(w), 377(w), 348(s), 256(s), 227(s) $\mathrm{cm}^{-1}$.

2-Sr. $4 \mathrm{H}_{2} \mathrm{O}$ : From $\mathrm{Sr}(\mathrm{OAc})_{2} \cdot 0.5 \mathrm{H}_{2} \mathrm{O}(0.43 \mathrm{~g}, 2.0 \mathrm{mmol}, 4$ Equiv.). The product precipitated as bright yellow, microcrystalline powder. Yield: $0.39 \mathrm{~g}$ (92\%). Dec. $470{ }^{\circ} \mathrm{C}$. Anal. calcd. for $\mathrm{C}_{10} \mathrm{H}_{16} \mathrm{~N}_{2} \mathrm{O}_{12} \mathrm{PtS}_{4} \mathrm{Sr}_{2}\left(M=854.73 \mathrm{~g} \mathrm{~mol}^{-1}\right)$ : C 14.05, H 1.89, N 3.28, S $15.00 \%$; found: C $14.07, \mathrm{H} 1.88, \mathrm{~N} 3.26, \mathrm{~S} 15.02 \% .{ }^{1} \mathrm{H}$ NMR: $\delta$ 4.16 (s; $\left.\mathrm{CH}_{2}\right)$ ppm. IR: v 3508(w br), 3430(w br), 3377(w br), 3078(w br), 2921(w), 1586(s), 1501(s), 1434(s), 1417(m), 1397(m), 1385(s), 1320(s), 1298(s), 1280(m), 1235(s), 1166(m), 1023(m), 994(w), 945(s), 913(s), 801(w br), 766(m br), 715(m), 635(m), 612(s), 556(s), 516(s), 439(m), 402(w), 373(w), 346(s), $250(\mathrm{~s}), 206(\mathrm{~s}) \mathrm{cm}^{-1}$. Single crystals of $2-\mathrm{Sr} \cdot 4 \mathrm{H}_{2} \mathrm{O}$ suitable for $X-$ ray structure determination were obtained by storing a mixture of $\left[\mathrm{Pt}\left(\mathrm{H}_{2} \mathrm{~L}\right)_{2}\right] \cdot 0.5 \mathrm{H}_{2} \mathrm{O} \quad\left(\mathbf{1} \cdot 0.5 \mathrm{H}_{2} \mathrm{O} ; 31 \mathrm{mg}, 0.05 \mathrm{mmol}\right)$ and $\mathrm{Sr}(\mathrm{OAc})_{2} \cdot 0.5 \mathrm{H}_{2} \mathrm{O}(43 \mathrm{mg}, 0.20 \mathrm{mmol})$ in $30 \mathrm{ml}$ water under hydrothermal conditions at $120^{\circ} \mathrm{C}$ for four days.

2-Ba·2 $\mathrm{H}_{2} \mathrm{O}$ : From $\mathrm{Ba}(\mathrm{OAc})_{2} \cdot \mathrm{H}_{2} \mathrm{O}(0.55 \mathrm{~g}, 2.0 \mathrm{mmol}, 4$ Equiv.). The product precipitated as light yellow, microcrystalline powder. Yield: $0.43 \mathrm{~g}$ (94\%). Dec. $430{ }^{\circ} \mathrm{C}$. Anal. calcd. for $\mathrm{C}_{10} \mathrm{H}_{12} \mathrm{Ba}_{2} \mathrm{~N}_{2} \mathrm{O}_{10} \mathrm{PtS}_{4}\left(M=918.21 \mathrm{~g} \mathrm{~mol}^{-1}\right): \mathrm{C} 13.08, \mathrm{H} 1.32, \mathrm{~N}$ 3.05, S $13.97 \%$; found: C $13.07, \mathrm{H} 1.35, \mathrm{~N} 3.04$, S $13.94 \% .{ }^{1} \mathrm{H}$ NMR: $\delta 4.15$ (s; $\left.\mathrm{CH}_{2}\right)$ ppm. IR: v 3574(w br), 3523(m), 3113(w br), 2973(w), 2916(w), 1615(s), 1595(s), 1512(s), 1430(m), 1390(s), 1385(s), 1322(s), 1294(s), 1268(s), 1235(s), 1165(m), 1024(s), 996(w), 945(s), 918(m), 910(s), 782(m), 751(s), 728(s), 633(s), 615(m), 577(s), 542(s), 527(m br), 489(s), 443(s), 409(m br), 391(w br), 363(w), 348(s), 333(w), 284(m), 228(s), 208(s) $\mathrm{cm}^{-1}$.

2-Fe $4 \mathrm{H}_{2} \mathrm{O}$ : From anhydrous $\mathrm{Fe}(\mathrm{OAc})_{2}(0.52 \mathrm{~g}, 3.0 \mathrm{mmol}, 6$ Equiv.). Due to the sensitivity of $\mathrm{Fe}(\mathrm{OAc})_{2}$ towards oxidation, this compound was prepared and isolated under an inert atmosphere of argon, using $\mathrm{O}_{2}$-free water and standard Schlenk techniques. After drying in vacuo, the bright yellow product showed no tendency towards oxidation. Yield: $0.32 \mathrm{~g}$ (81\%). Dec. $395{ }^{\circ} \mathrm{C}$. Anal. calcd. for $\mathrm{C}_{10} \mathrm{H}_{16} \mathrm{Fe}_{2} \mathrm{~N}_{2} \mathrm{O}_{12} \mathrm{PtS}_{4}(M=791.27 \mathrm{~g}$ $\mathrm{mol}^{-1}$ ): C 15.18, H 2.04, N 3.54, S $16.21 \%$; found: C 15.19, H 2.08, N 3.55, S $16.21 \% .{ }^{1} \mathrm{H}$ NMR: $\delta 4.33$ (s; $\left.\mathrm{CH}_{2}\right)$ ppm. IR: v 3531(w), 3275(m br), 3144(m br), 1586(s), 1512(s), 1423(s), 1394(m), 1384(s), 1305(s), 1242(s), 1171(s), 1030(m), 998(w), 954(m), 907(m), 805(m br), 732(s br), 697(w br), 610(s), 548(s), 403(m br), 357(s), 280(s), 254(s), 226(s) $\mathrm{cm}^{-1}$. Single crystals of 2$\mathrm{Fe} \cdot 14 \mathrm{H}_{2} \mathrm{O}$ suitable for $\mathrm{X}$-ray structure determination were obtained from the concentrated mother liquor at ambient temperature.

2- $\mathrm{Cu} \cdot 8 \mathrm{H}_{2} \mathrm{O}$ : From $\mathrm{Cu}(\mathrm{OAc})_{2} \cdot \mathrm{H}_{2} \mathrm{O}(0.40 \mathrm{~g}, 2.0 \mathrm{mmol}, 4$ Equiv.). The product precipitated as an amorphous, greenish-brown solid, which turned into brown powder upon isolation. Yield: $0.40 \mathrm{~g}$ (91\%). Dec. $182{ }^{\circ} \mathrm{C}$. Anal. calcd. for $\mathrm{C}_{10} \mathrm{H}_{24} \mathrm{Cu}_{2} \mathrm{~N}_{2} \mathrm{O}_{16} \mathrm{PtS}_{4}(M=$ $\left.878.74 \mathrm{~g} \mathrm{~mol}^{-1}\right)$ : C $13.67, \mathrm{H} \mathrm{2.75}, \mathrm{N} 3.19$, S $14.60 \%$; found: C 13.69, H 2.74, N 3.18, S $14.61 \%$. Meaningful NMR data could not be obtained due to the paramagnetic nature of the compound. IR: v 3560(w br), 2979(w), 1637(m), 1598(s), 1489(s), 1427(s), 1412(m), 1406(m), 1393(s), 1316(s), 1286(w), 1268(w), 1226(s), 1173(m), 1029(m), 1003(m), 946(m), 607(s), 807(w), 764(m), 735(m),726(m), 663(m), 641(s), 566(m), 454(s br), 423(w br), 401(m br), 354(s), 330(m), 317(w), 308(m), 279(w), 228(s) $\mathrm{cm}^{-1}$.

2-Cd. $4 \mathrm{H}_{2} \mathrm{O}$ : From $\mathrm{Cd}(\mathrm{OAc})_{2} \cdot 2 \mathrm{H}_{2} \mathrm{O}(0.53 \mathrm{~g}, 2.0 \mathrm{mmol}, 4$ Equiv.). The product precipitated as yellow, microcrystalline powder. Yield: $371 \mathrm{mg}$ (82\%). Dec. $350{ }^{\circ} \mathrm{C}$. Anal. calcd. for $\mathrm{C}_{10} \mathrm{H}_{16} \mathrm{Cd}_{2} \mathrm{~N}_{2} \mathrm{O}_{12} \mathrm{PtS}_{4}\left(M=904.41 \mathrm{~g} \mathrm{~mol}^{-1}\right): \mathrm{C} 13.28, \mathrm{H} 1.78, \mathrm{~N}$ 3.10, S $14.18 \%$; found: C $13.27, \mathrm{H} 1.79, \mathrm{~N} 3.10$, S $14.17 \% .{ }^{1} \mathrm{H}$ NMR: $\delta 4.16\left(\mathrm{~s} ; \mathrm{CH}_{2}\right)$ ppm. IR: v 3522(w), 3494(m), 2933(m br), 1594(s), 1553(s), 1513(s), 1440(s), 1423(m), 1389(s), 1308(s), 1285(m), 1237(s), 1173(s), 1027(m), 997(w), 951(m), 922(m), 850(w br), 733(s), 666(w br), 643(m), 614(w), 607(m), 563(m), 530(s), 466(w br), 439(m), 398(w), 373(w), 350(s), 336(m), 
$311(\mathrm{~s}), 213(\mathrm{~s}) \mathrm{cm}^{-1}$. Single crystals of $\mathbf{2}-\mathbf{C d} \cdot 4 \mathrm{H}_{2} \mathrm{O}$ suitable for $\mathrm{X}-$ ray structure determination were obtained by storing a mixture of $\left[\mathrm{Pt}\left(\mathrm{H}_{2} \mathrm{~L}\right)_{2}\right] \cdot 0.5 \mathrm{H}_{2} \mathrm{O} \quad\left(\mathbf{1} \cdot 0.5 \mathrm{H}_{2} \mathrm{O} ; 31 \mathrm{mg}, 0.05 \mathrm{mmol}\right)$ and $\mathrm{Cd}(\mathrm{OAc})_{2} \cdot 2 \mathrm{H}_{2} \mathrm{O}(53 \mathrm{mg}, 0.20 \mathrm{mmol})$ in $30 \mathrm{ml}$ water under hydrothermal conditions at $120^{\circ} \mathrm{C}$ for $24 \mathrm{~h}$.

\section{Conflicts of interest}

There are no conflicts to declare.

\section{Acknowledgements}

General financial support by the Otto-von-Guericke-Universität Magdeburg is gratefully acknowledged.

\section{References}

S. R. Batten, N. R. Champness, X.-M. Chen, J. GarciaMartinez, S. Kitagawa, L. Öhrström, M. O. Keeffe, M. P. Suh and J. Reedijk, Pure. Appl. Chem., 2013, 85, 1715-1724. H. Furukawa, N. Ko, Y. B. Go, N. Aratani, S. B. Choi, E. Choi, A. Ö. Yazaydin, R. Q. Snurr, M. O'Keeffe, J. Kim and O. M. Yaghi, Science, 2010, 329, 424-428. S. R. Zhang, D. Y. Du, K. Tan, J. S. Qin, H. Q. Dong, S. L. Li, W. W. He, Y. Q. Lan, P. Shen and Z. M. Su, Chem. Eur. J., 2013, 19, 11279-11286. L. Piñeiro-López, F. J. Valverde-Muñoz, M. Seredyuk, M. C. Muñoz, M. Haukka and J. A. Real, Inorg. Chem., 2017, 56, 7038-7047. and P. Cheng, Dalt. Trans., 2017, 46, 3526-3534.

H. Gildenast, S. Nölke and U. Englert, CrystEngComm, 2020, 22, 1041-1049.

D. Kim, H. Ha, Y. Kim, Y. Son, J. Choi, M. H. Park, Y. Kim, M. Yoon, H. Kim, D. Kim and M. Kim, Cryst. Growth Des., 2020, 20, 5338-5345.

P. Liebing, J. Witzorke, F. Oehler and M. Schmeide, Inorg. Chem., 2020, 59, 2825-2832.

P. Liebing, F. Oehler and J. Witzorke, Crystals, 2020, 10, 505.

G. Hogarth, Transition metal dithiocarbamates: 1978-2003, 2005, vol. 53.

A. Earnshaw, Introduction to Magnetochemisty, Academic Press, London, 1968.

R. Tsuchida, Bull. Chem. Soc. Jpn., 1938, 13, 388-400.

L. Ouahab, Chem. Mater., 1997, 9, 1909-1926.

S. Ohba, M. Kato, T. Tokii, Y. Muto and O. W. Steward, Mol. Cryst. Liq. Cryst. Sci. Technol. Sect. A. Mol. Cryst. Liq. Cryst., 1993, 233, 335-344.

D. E. Irish, J. Semmler, N. J. Taylor and G. E. Toogood, Acta Crystallogr., 1991, C47, 2322-2324.

E. F. Bertaut, D. Tran Qui, P. Burlet, P. Burlet, M. Thomas and J. M. Moreau, Acta Crystallogr., 1974, B30, 2234-2236. A. N. Sobolev, E. B. Miminoshvili, K. E. Miminoshvili and T.
N. Sakvarelidze, Acta Crystallogr., 2003, E59, m836-m837. T. C. Downie, W. Harrison, E. S. Raper and M. A. Hepworth, Acta Crystallogr., 1971, B27, 706-712.

M. Lutz and A. L. Spek, Acta Crystallogr., 2009, C65, 69-74. P. van der Sluis, A. Schouten and A. L. Spek, Acta Crystallogr., 1987, C43, 1922-1924.

V. K. Trunov, A. D. Chubinidze, V. A. Efremov and Y. A. Velikodni, Koord. khimiia, 1984, 10, 403.

G. Leyva, G. Polla, M. T. Garland and R. Baggio, Acta Crystallogr., 2007, C63, m534-m536.

W. Harrison and J. Trotter, J. Chem. Soc. Dalt. Trans., 1971, 956-960.

A. Thakur and A. Yadav, Acta Cienc. Indica. Phys. C. L. Perrin, J. S. Lau, Y. J. Kim, P. Karri, C. Moore and A. L. Rheingold, J. Am. Chem. Soc., 2009, 131, 13548-13554. R. D. Shannon, Acta Crystallogr., 1976, A32, 751-767. T. P. Hanusa, in Comprehensive Coordination Chemistry II, 2003, pp. 1-92.

R. Baggio, A. Frigerio, E. B. Halac, D. Vega and M. Perec, J. Chem. Soc. Dalt. Trans., 1992, 549-554.

K. K. Manar, M. K. Yadav, Anamika, M. G. B. Drew and N. Singh, Polyhedron, 2016, 117, 592-599.

J. Ahmad, F. N.-F. How, S. N. A. Halim, M. M. Jotani, S. M. Lee and E. R. T. Tiekink, Z. Krist. - Cryst. Mater., 2019, 234, 341-349.

Z. B. Leka, V. M. Leovac, S. Lukić, T. J. Sabo, S. R. Trifunović and K. M. Szécsényi, J. Therm. Anal. Calorim., 2006, 83, 687-691.

G. Foex and G. J. Gorter, A collection of diamagnetic and paramagnetic susceptibilities, Masson, Paris, 1957. G. M. Sheldrick, Acta Crystallogr., 2015, A71, 3-8. G. M. Sheldrick, Acta Crystallogr., 2015, C71, 3-8. O. V. Dolomanov, L. J. Bourhis, R. J. Gildea, J. A. K. Howard and H. Puschmann, J. Appl. Crystallogr., 2009, 42, 339-341. $X$-Area, X-Red and X-Shape, STOE \& Cie 2002, Darmstadt, Germany. 


\section{Supporting Information}

From zero- to three-dimensional heterobimetallic coordination polymers with the $\left[\mathrm{Pt}\left\{\mathrm{SSC}-\mathrm{N}\left(\mathrm{CH}_{2} \mathrm{COO}\right)_{2}\right\}_{2}\right]^{4-}$ metalloligand

Phil Liebing, ${ }^{* a}$ Florian Oehler, ${ }^{b}$ Juliane Witzorke, ${ }^{a}$ and Marten Schmeide ${ }^{a}$

a Otto-von-Guericke-Universität Magdeburg, Chemisches Institut, Universitätsplatz 2, 39106 Magdeburg, Germany

b Martin-Luther-Universität Halle-Wittenberg, Institut für Chemie, Kurt-Mothes-Str. 2, 06120 Halle (Saale), Germany

* E-Mail: phil.liebing@ovgu.de

Table of Contents

1. Single-crystal $X$-ray structural analyses

2. Powder X-ray diffraction studies

3. Thermal analyses 


\section{Single-crystal $X$-ray structural analyses}

Table S1. Crystal data and details on structure refinement for the reported compounds. ${ }^{a}$ Diffuse electron density in voids assigned to additional, disordered $\mathrm{H}_{2} \mathrm{O}$ molecules.

\begin{tabular}{|c|c|c|c|c|c|c|c|}
\hline Compound & $\begin{array}{c}2-\mathrm{Mg} \cdot 12 \mathrm{H}_{2} \mathrm{O} \\
\text {-acetone } \cdot \text { solvent }\end{array}$ & $2-\mathrm{Sr} \cdot 4 \mathrm{H}_{2} \mathrm{O}$ & 2-Mn $9 \mathrm{H}_{2} \mathrm{O} \cdot$ solvent $^{\mathrm{a}}$ & 2-Fe' $14 \mathrm{H}_{2} \mathrm{O}$ & $\begin{array}{c}\text { 2-Co. } 12 \mathrm{H}_{2} \mathrm{O} \\
\text { solvent } \\
\end{array}$ & $\begin{array}{c}\text { 2- } \mathrm{Ni} \cdot 12 \mathrm{H}_{2} \mathrm{O} \\
\text { solvent }\end{array}$ & $2-\mathrm{Cd} \cdot 4 \mathrm{H}_{2} \mathrm{O}$ \\
\hline CCDC deposition number & 2032166 & 2032167 & 2032168 & 2032169 & 2032170 & 2032171 & 2032172 \\
\hline Molecular formula sum & $\mathrm{C}_{13} \mathrm{H}_{38} \mathrm{Mg}_{2} \mathrm{~N}_{2} \mathrm{O}_{21} \mathrm{PtS}_{4}$ & $\mathrm{C}_{10} \mathrm{H}_{16} \mathrm{~N}_{2} \mathrm{O}_{12} \mathrm{PtS}_{4} \mathrm{Sr}_{2}$ & $\mathrm{C}_{10} \mathrm{H}_{26} \mathrm{Mn}_{2} \mathrm{~N}_{2} \mathrm{O}_{17} \mathrm{PtS}_{4}$ & $\mathrm{C}_{10} \mathrm{H}_{36} \mathrm{Fe}_{2} \mathrm{~N}_{2} \mathrm{O}_{22} \mathrm{PtS}_{4}$ & $\mathrm{C}_{10} \mathrm{H}_{32} \mathrm{Co}_{2} \mathrm{~N}_{2} \mathrm{O}_{20} \mathrm{PtS}_{4}$ & $\mathrm{C}_{10} \mathrm{H}_{32} \mathrm{~N}_{2} \mathrm{Ni}_{2} \mathrm{O}_{20} \mathrm{PtS}_{4}$ & $\mathrm{C}_{10} \mathrm{H}_{16} \mathrm{Cd}_{2} \mathrm{~N}_{2} \mathrm{O}_{12} \mathrm{PtS}_{4}$ \\
\hline Formula weight / $\mathrm{g} \mathrm{mol}^{-1}$ & 930.40 & 854.82 & 879.54 & 971.44 & 941.56 & 941.12 & 904.38 \\
\hline Crystal system & orthorhombic & triclinic & monoclinic & monoclinic & triclinic & triclinic & triclinic \\
\hline Space group & Pnma & $\mathrm{P} \overline{1}$ & $\mathrm{C} 2 / \mathrm{c}$ & $\mathrm{P} 2_{1} / \mathrm{n}$ & $\mathrm{P} \overline{1}$ & $\mathrm{P} \overline{1}$ & $\mathrm{P} \overline{1}$ \\
\hline Cell metric & $10.4292(2)$ & $6.8663(6)$ & $25.8063(6)$ & $6.3190(2)$ & $6.2781(4)$ & $6.2643(3)$ & $6.7533(3)$ \\
\hline$b / \AA$ & $15.3858(3)$ & $7.9281(7)$ & $10.7668(2)$ & $13.7134(4)$ & $13.687(1)$ & $13.6027(7)$ & $7.4688(4)$ \\
\hline$c / \AA$ & $26.9006(4)$ & $11.540(1)$ & $23.2567(5)$ & $16.9778(6)$ & $14.252(1)$ & $14.2439(6)$ & $11.3350(5)$ \\
\hline$\alpha /$ deg. & 90 & $94.147(7)$ & 90 & 90 & $117.626(5)$ & $117.142(3)$ & $103.510(4)$ \\
\hline$\beta /$ deg. & 90 & $101.197(7)$ & $90.720(2)$ & $97.989(3)$ & $92.748(6)$ & $92.957(4)$ & $97.371(4)$ \\
\hline$\gamma /$ deg. & 90 & $114.893(7)$ & 90 & 90 & $100.521(6)$ & $99.353(4)$ & $103.462(4)$ \\
\hline Cell volume / $\AA^{3}$ & $4316.5(1)$ & $550.53(9)$ & $6461.4(2)$ & $1456.93(8)$ & $1054.34(14)$ & 1054.74(9) & $530.45(5)$ \\
\hline Molecules per cell $z$ & 4 & 1 & 8 & 2 & 1 & 1 & 1 \\
\hline Electrons per cell $F_{000}$ & 1856 & 404 & 3424 & 960 & 462 & 464 & 424 \\
\hline Calcd. density $\rho / \mathrm{g} \mathrm{cm}^{-3}$ & 1.432 & 2.578 & 1.808 & 2.214 & 1.483 & 1.482 & 2.831 \\
\hline$\mu / \mathrm{mm}^{-1}\left(\mathrm{Mo}^{-\mathrm{K}_{\alpha}}\right)$ & 3.536 & 11.604 & 5.409 & 6.150 & 4.341 & 4.446 & 9.019 \\
\hline Crystal shape and colour & yellow block & yellow plate & light brown block & yellow needle & light pink needle & pale green needle & yellow prism \\
\hline Crystal size / mm & $0.42 \times 0.20 \times 0.18$ & $0.25 \times 0.05 \times 0.02$ & $0.39 \times 0.34 \times 0.21$ & $0.39 \times 0.03 \times 0.02$ & $0.36 \times 0.04 \times 0.02$ & $0.39 \times 0.05 \times 0.03$ & $0.26 \times 0.13 \times 0.07$ \\
\hline$\theta$ range / deg. & $2.094 \ldots 27.443$ & $2.876 \ldots 24.996$ & $2.050 \ldots 27.000$ & $2.423 \ldots 29.278$ & $2.866 \ldots 25.993$ & $2.869 \ldots 26.997$ & $2.915 \ldots 29.168$ \\
\hline Reflections collected & 66911 & 4438 & 36799 & 13685 & 8827 & 11143 & 8716 \\
\hline Reflections unique & 5060 & 1935 & 7050 & 3922 & 4066 & 4585 & 2852 \\
\hline Reflections with $I>2 \sigma(I)$ & 4426 & 1530 & 6661 & 3419 & 3527 & 4129 & 2810 \\
\hline Completeness of dataset & $99.9 \%$ & $99.7 \%$ & $100 \%$ & $100 \%$ & $98.5 \%$ & $99.9 \%$ & $99.9 \%$ \\
\hline$R_{\text {int }}$ & 0.0369 & 0.0864 & 0.0744 & 0.0384 & 0.0567 & 0.0307 & 0.0414 \\
\hline Parameters; Restraints & $240 ; 1$ & $155 ; 59$ & $336 ; 2$ & $230 ; 15$ & $191 ; 0$ & $191 ; 0$ & $159 ; 4$ \\
\hline$R_{1}($ all data, $I>2 \sigma(I))$ & $0.0313 ; 0.0272$ & $0.0849 ; 0.0597$ & $0.0310 ; 0.0291$ & $0.0382 ; 0.0294$ & $0.0508 ; 0.0405$ & $0.0333 ; 0.0274$ & $0.0172 ; 0.0167$ \\
\hline$w R_{2}$ (all data, $\left.I>2 \sigma(I)\right)$ & $0.0673 ; 0.0656$ & $0.1799 ; 0.1477$ & $0.0726 ; 0.0716$ & $0.0616 ; 0.0587$ & $0.1070 ; 0.0983$ & $0.0701 ; 0.0666$ & $0.0445 ; 0.0442$ \\
\hline $\operatorname{GooF}\left(F^{2}\right)$ & 1.150 & 1.188 & 1.030 & 1.184 & 1.059 & 1.044 & 1.104 \\
\hline Max. residual peaks & $-0.534 ; 0.911$ & $-1.878 ; 1.890$ & $-1.897 ; 0.652$ & $-1.296 ; 1.170$ & $-1.757 ; 1.245$ & $-0.674 ; 0.558$ & $-0.950 ; 0.795$ \\
\hline Extinction coefficient & $0.00045(4)$ & $0.008(2)$ & - & $0.0012(1)$ & - & - & $0.0045(4)$ \\
\hline
\end{tabular}




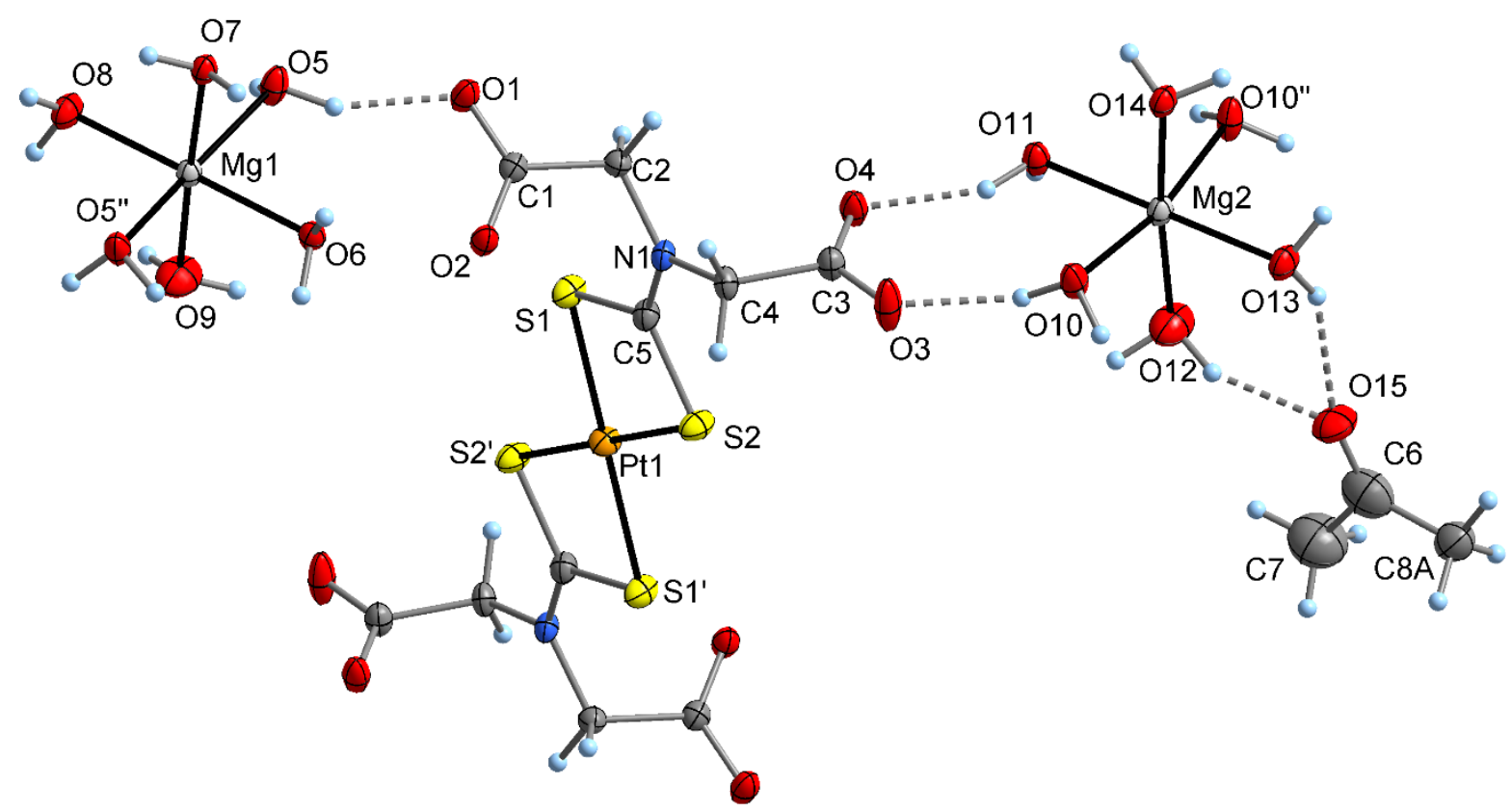

Figure S1. Molecular structure of $\mathrm{H}_{2} \mathrm{O}$ - and acetone-solvated $\mathrm{Mg}_{2}\left[\mathrm{Pt}(\mathrm{L})_{2}\right](\mathbf{2}-\mathbf{M g})$ in the crystal, showing the atom numbering scheme. Displacement ellipsoids drawn at the $50 \%$ probability level. The atom Pt1 is situated on a crystallographic centre of inversion, and the atoms Mg1, Mg2, 06-09 and 011$\mathrm{O} 15$ and $\mathrm{C6}, \mathrm{C7}$ and C8A on crystallographic mirror planes. Selected intermolecular distances (pm) and angles ( ${ }^{\circ}$ ): Pt1-S1 231.01(8), Pt1-S2 231.62(8), Mg1-05 204.6(2), Mg1-06 206.7(3), Mg1-07 209.9(3), Mg1-O8 205.1(3), Mg1-09 205.7(4), Mg2-010 203.0(2), Mg1-O11 207.8(3), Mg1-012 207.5(4), Mg1O13 207.3(3), Mg1-O14 210.6(3), C5-S1 172.6(3), C5-S2 171.6(3), C5-N1 131.4(4), S1-Pt1-S2 75.60(3), S1-Pt1-S2' 104.41(3), S1-C5-S2 110.9(2). 


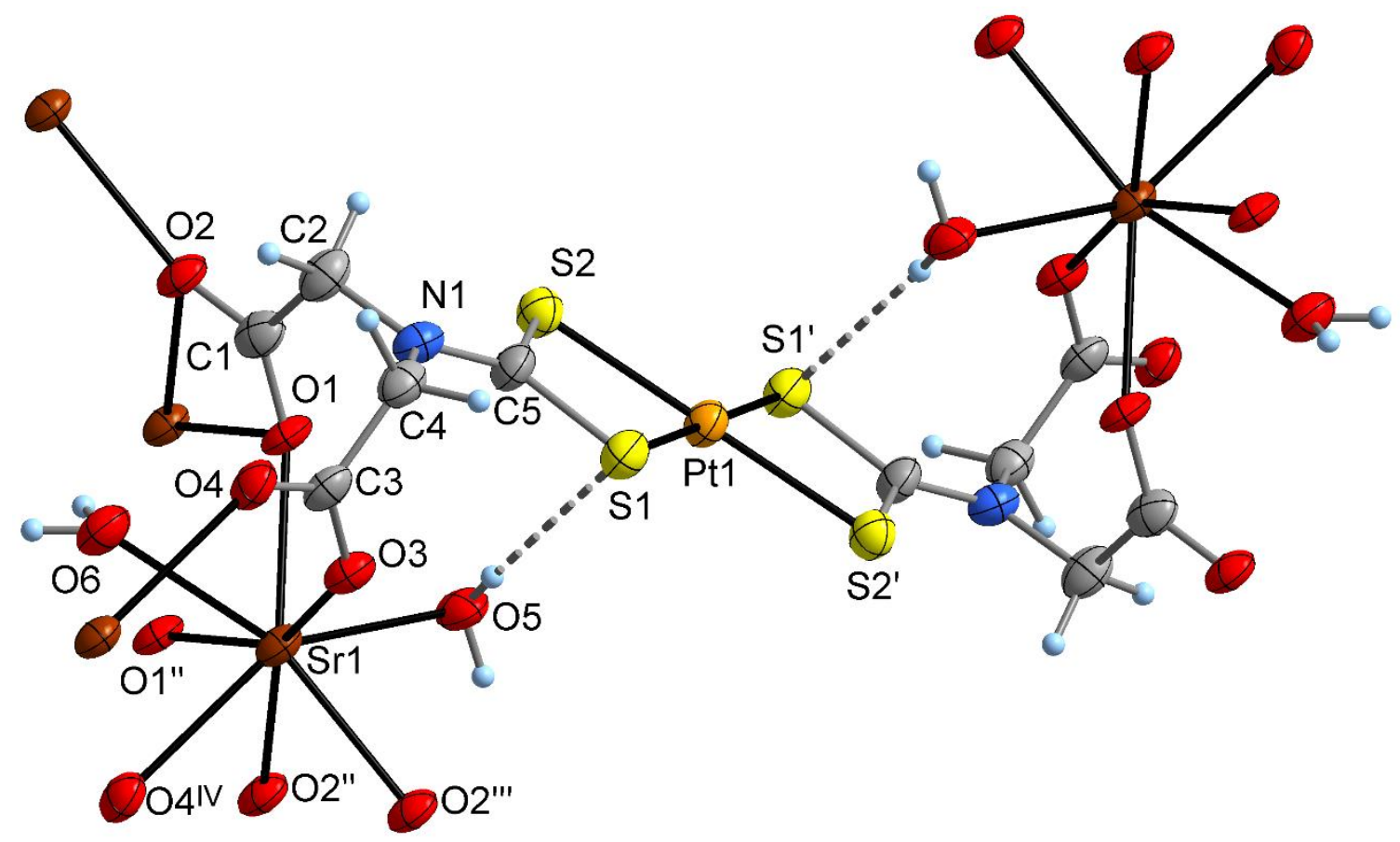

Figure S2. Molecular structure of $\mathrm{Sr}_{2}\left[\mathrm{Pt}(\mathrm{L})_{2}\right](2-\mathrm{Sr}) \cdot 4 \mathrm{H}_{2} \mathrm{O}$ in the crystal, showing the atom numbering scheme. Displacement ellipsoids drawn at the $50 \%$ probability level. The Pt atom is situated on a crystallographic centre of inversion. Selected intermolecular distances (pm) and angles ( $\left.{ }^{\circ}\right)$ : Pt1-S1 232.2(4), Pt1-S2 231.5(4), Sr1-01 252(1), Sr1-01" 266(1), Sr1-O2" 268(1), Sr1-O2"” 250(1), Sr1-03 248(1), Sr1-O4V 263(1), Sr1-05 261(1), Sr1-O6 257(1), C5-S1 172(2), C5-S2 172(2), C5-N1 135(2), S1Pt1-S2 75.4(2), S1-Pt1-S2' 104.6(2), 01-Sr1-O1" 75.9(4), O1-Sr1-O2" 115.3(4), O1-Sr1-O2"' 139.6(4), 01-Sr1-03 83.5(4), 01-Sr1-04IV 138.1(4), 01-Sr1-05 70.7(4), 01-Sr1-06 67.4(4), 01"'-Sr1-02" 49.1(3), O1"-Sr1-O2"' 120.6(4), O1"'-Sr1-O3 155.0(3), O1"'-Sr1-O4'v 85.0(4), O1"-Sr1-05 86.7(4), O1"'-Sr1-O6 81.3(4), O2"'-Sr1-O2"' 71.5(4), O2"-Sr1-O3 155.8(3), O2"-Sr1-O4V 74.9(4), O2"'-Sr1-O5 74.5(4), O2"'Sr1-O6 122.3(4), O2'"'-Sr1-O3 84.3(4), O2"'-Sr1-O4'v 82.1(4), O2'"'-Sr1-O5 73.7(4), O2"'-Sr1-O6 145.5(4), O3-Sr1-O4IV 101.7(4), O3-Sr1-O5 99.7(4), O3-Sr1-O6 77.9(4), O4IV-Sr1-O5 145.7(4), O4 ${ }^{\mathrm{IV}-S r 1-}$ 06 73.1(4), 05-Sr1-06 138.1(4), S1-C5-S2 111.0(9). 


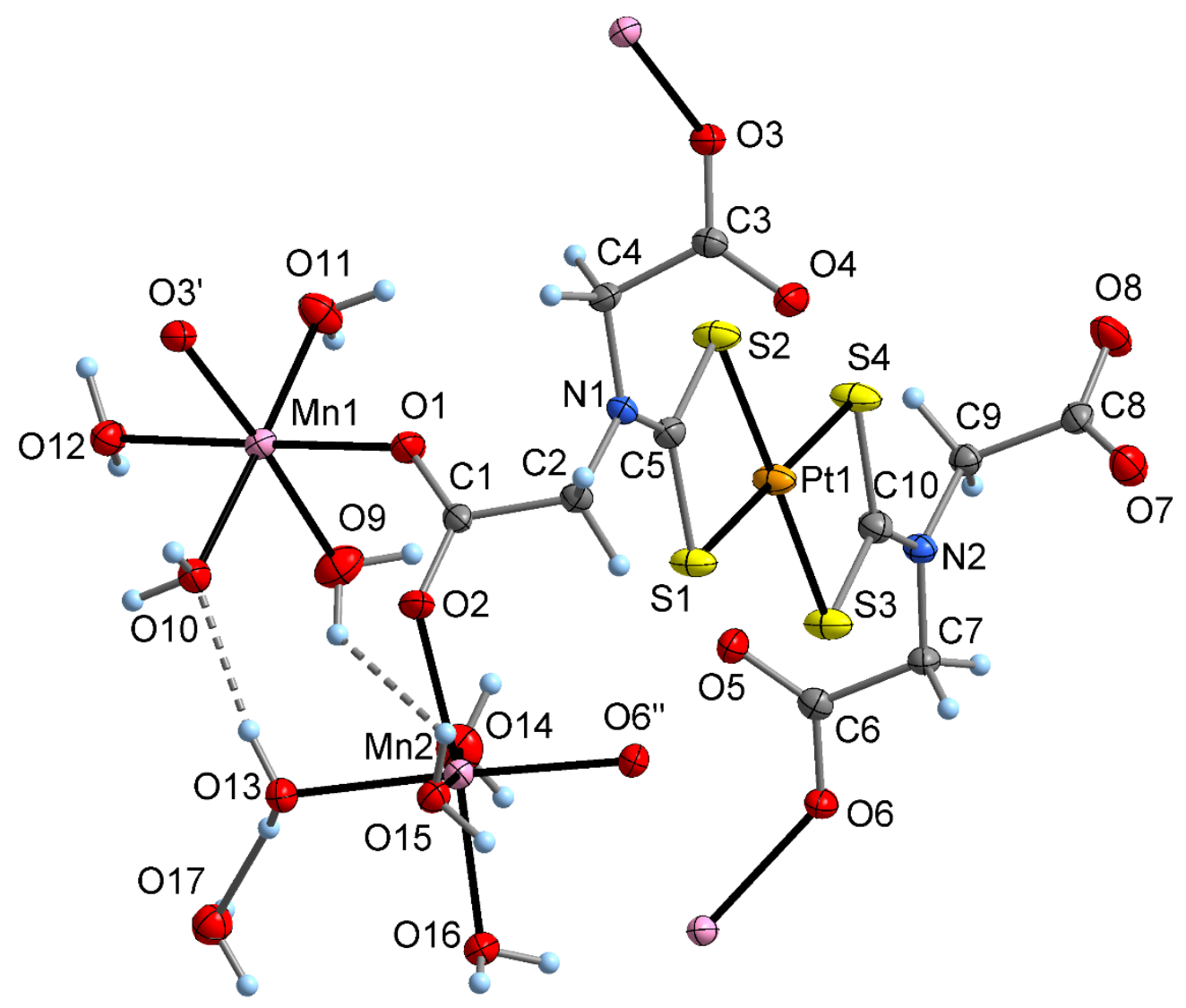

Figure S3. Molecular structure of hydrated $\mathrm{Mn}_{2}\left[\mathrm{Pt}(\mathrm{L})_{2}\right]$ (2-Mn) in the crystal, showing the atom numbering scheme. Displacement ellipsoids drawn at the $50 \%$ probability level. Selected intermolecular distances (pm) and angles $\left({ }^{\circ}\right)$ : Pt1-S1 231.2(1), Pt1-S2 231.6(1), Pt1-S3 231.9(1), Pt1-S4 231.6(1), Mn1-O1 211.6(3), Mn1-O3' 215.1(3), Mn1-O9 224.9(3), Mn1-O10 214.8(3), Mn1-O11 217.1(3), Mn1-O12 222.7(3), Mn2-O2 214.7(2), Mn2-O6" 217.1(2), Mn2-013 220.1(2), Mn2-O14 216.1(3), Mn2-O15 216.5(3), Mn2-O16 217.2(3), C5-S1 172.2(4), C5-S2 172.2(4), C10-S3 172.5(4), C10S4 172.5(4), C5-N1 131.1(5), C10-N2 130.9(5), S1-Pt1-S2 75.45(3), S1-Pt1-S3 104.47(3), S1-Pt1-S4 179.79(4), S2-Pt1-S3 178.73(4), S2-Pt1-S4 104.64(3), S3-Pt1-S4 75.44(3), O1-Mn1-O3' 94.7(1), O1-Mn109 86.3(1), O1-Mn1-010 91.4(1), O1-Mn1-011 92.1(1), 01-Mn1-012 178.4(1), O3'-Mn1-09 175.8(1), O3'-Mn1-O10 86.6(1), O3'-Mn1-O11 94.7(1), O3'-Mn1-O12 86.2(1), O2-Mn2-O6" 98.5(1), O2-Mn2O13 83.6(1), O2-Mn2-O14 87.2(1), O2-Mn2-O15 89.8(1), O2-Mn2-O16 173.2(1), O6"-Mn2-013 O6"Mn2-014 97.8(1), O6"'-Mn2-O15 90.0(1), 177.5(1), O6"'-Mn2-O16 88.2(1), S1-C5-S2 110.7(2), S3-C10S4 110.5(2). 


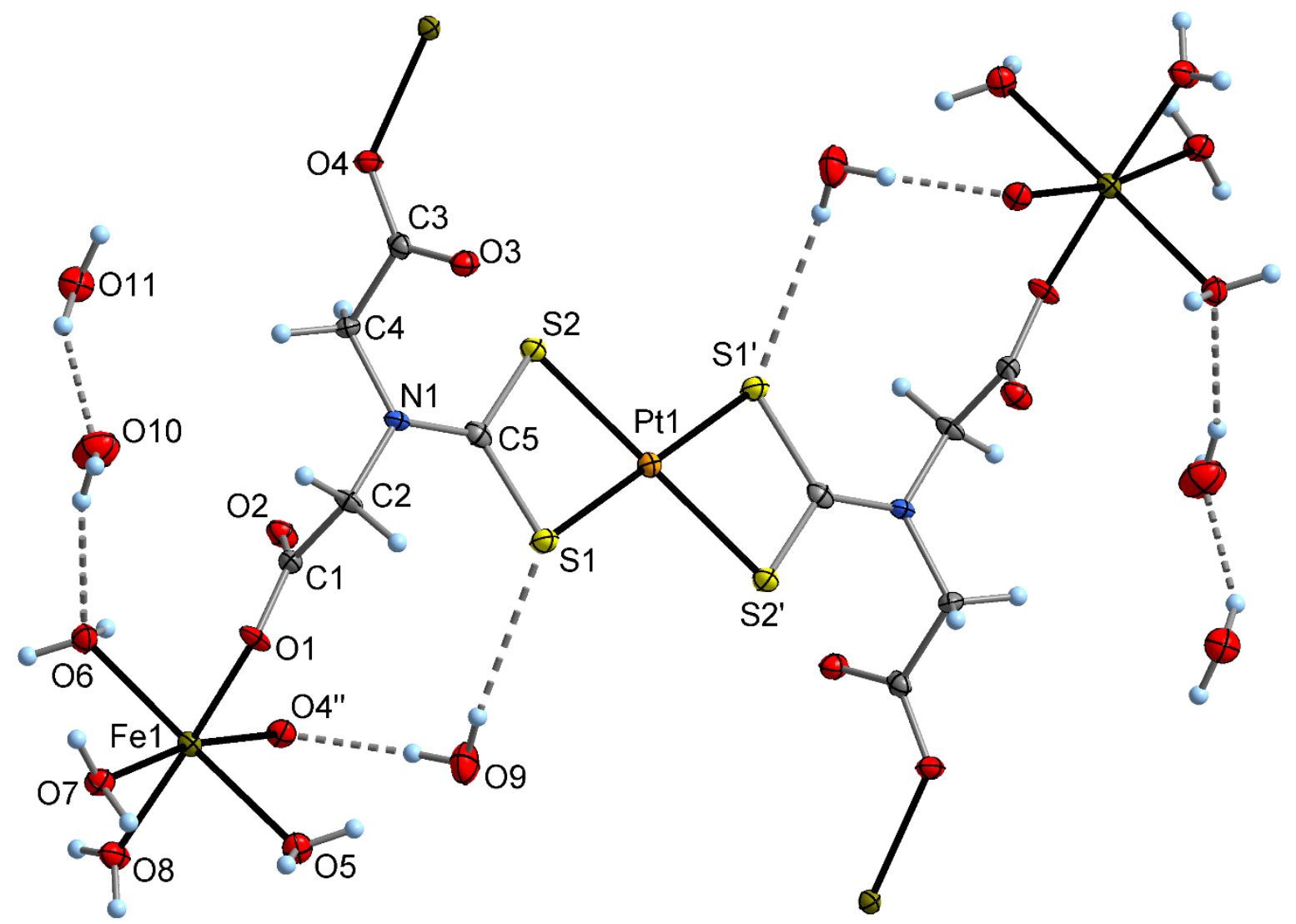

Figure S4. Molecular structure of $\mathrm{Fe}_{2}\left[\mathrm{Pt}(\mathrm{L})_{2}\right](2-\mathrm{Fe}) \cdot 14 \mathrm{H}_{2} \mathrm{O}$ in the crystal, showing the atom numbering scheme. Displacement ellipsoids drawn at the $50 \%$ probability level. The Pt atom is situated on a crystallographic centre of inversion. Selected intermolecular distances $(\mathrm{pm})$ and angles $\left({ }^{\circ}\right)$ : Pt1-S1 231.9(1), Pt1-S2 230.8(1), Fe1-O1 205.7(3), Fe1-O4' 212.3(3), Fe1-O5 220.2(3), Fe1-O6 217.5(3), Fe1$\mathrm{O} 7$ 216.0(3), Fe1-O8 210.0(3), C5-S1 172.7(4), C5-S2 171.4(4), C5-N1 131.8(5), S1-Pt1-S2 75.36(3), S1Pt1-S2' 104.64(3), O1-Fe1-O4' 97.6(1), O1-Fe1-O5 88.8(1), 01-Fe1-O6 89.7(1), 01-Fe1-07 89.6(1), O1Fe1-O8 173.8(1), O4'-Fe1-05 85.2(1), O4'-Fe1-06 95.5(1), O4'-Fe1-07 169.8(1), O4'-Fe1-O8 88.5(1), S1-C5-S2 110.6(2). 


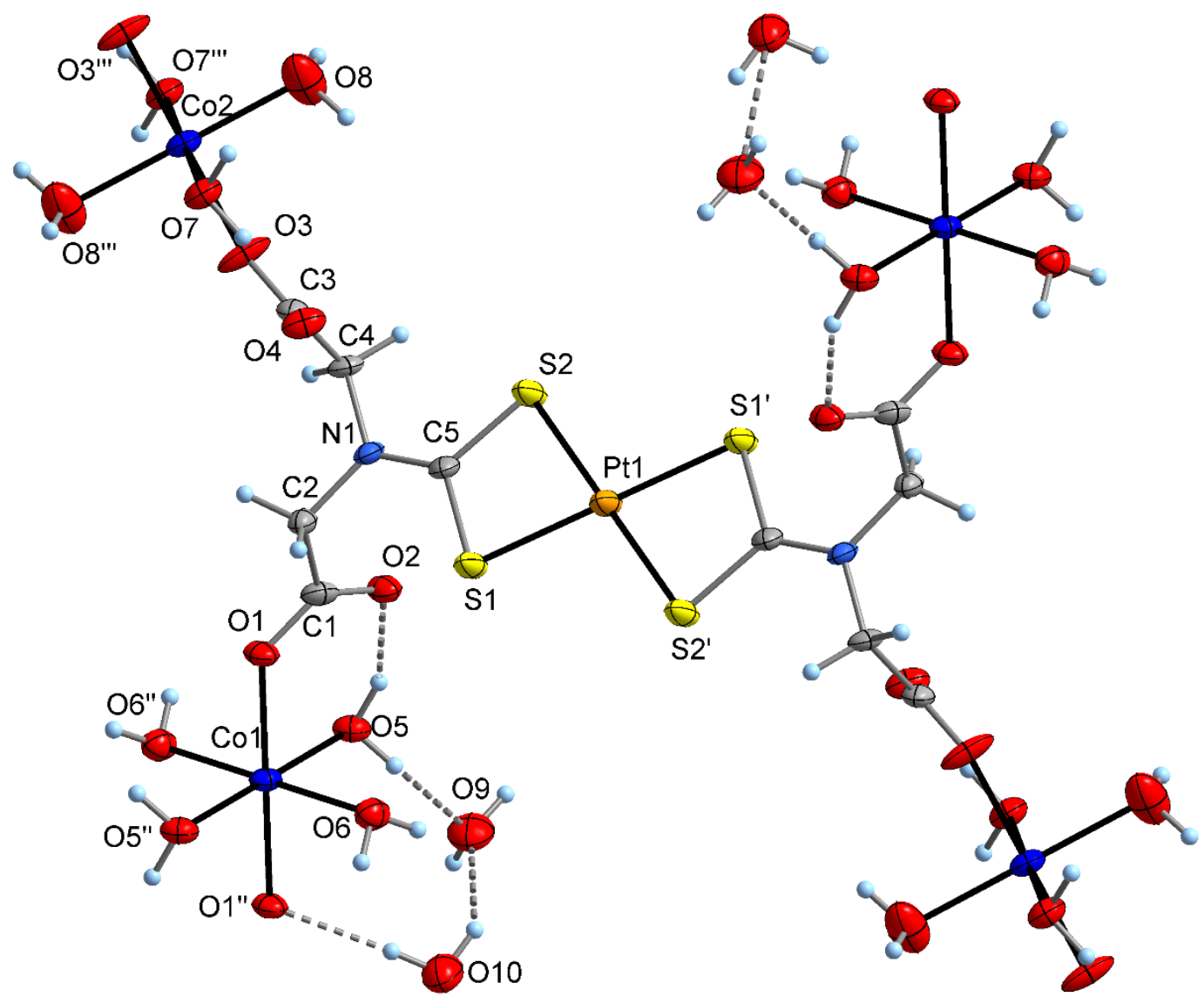

Figure S5. Molecular structure of hydrated $\mathrm{Co}_{2}\left[\mathrm{Pt}(\mathrm{L})_{2}\right]$ (2-Co) in the crystal, showing the atom numbering scheme. Displacement ellipsoids drawn at the $50 \%$ probability level. The Co and Pt atoms are situated on crystallographic centres of inversion. Selected intermolecular distances (pm) and angles ( ${ }^{\circ}$ ): Pt1-S1 230.8(2), Pt1-S2 232.4(1), Co1-01 209.3(4), Co1-05 213.2(4), Co1-06 206.8(4), Co2O3 207.5(4), Co2-O7 210.9(4), Co2-O8 207.4(5), C5-S1 172.9(6), C5-S2 172.2(6), C5-N1 130.1(7), S1Pt1-S2 75.60(5), S1-Pt1-S2' 104.40(5), O1-Co1-O5 88.1(2), 01-Co1-O5" 91.9(2), 01-Co1-O6 91.7(2), O1Co1 O6" 88.3(2), O3-Co2-07 89.9(2), O3-Co2-O7"' 90.1(2), O3-Co2-O8 90.9(2), O3-Co2-O8'" 89.1(2), S1-C5-S2 110.7(3). 


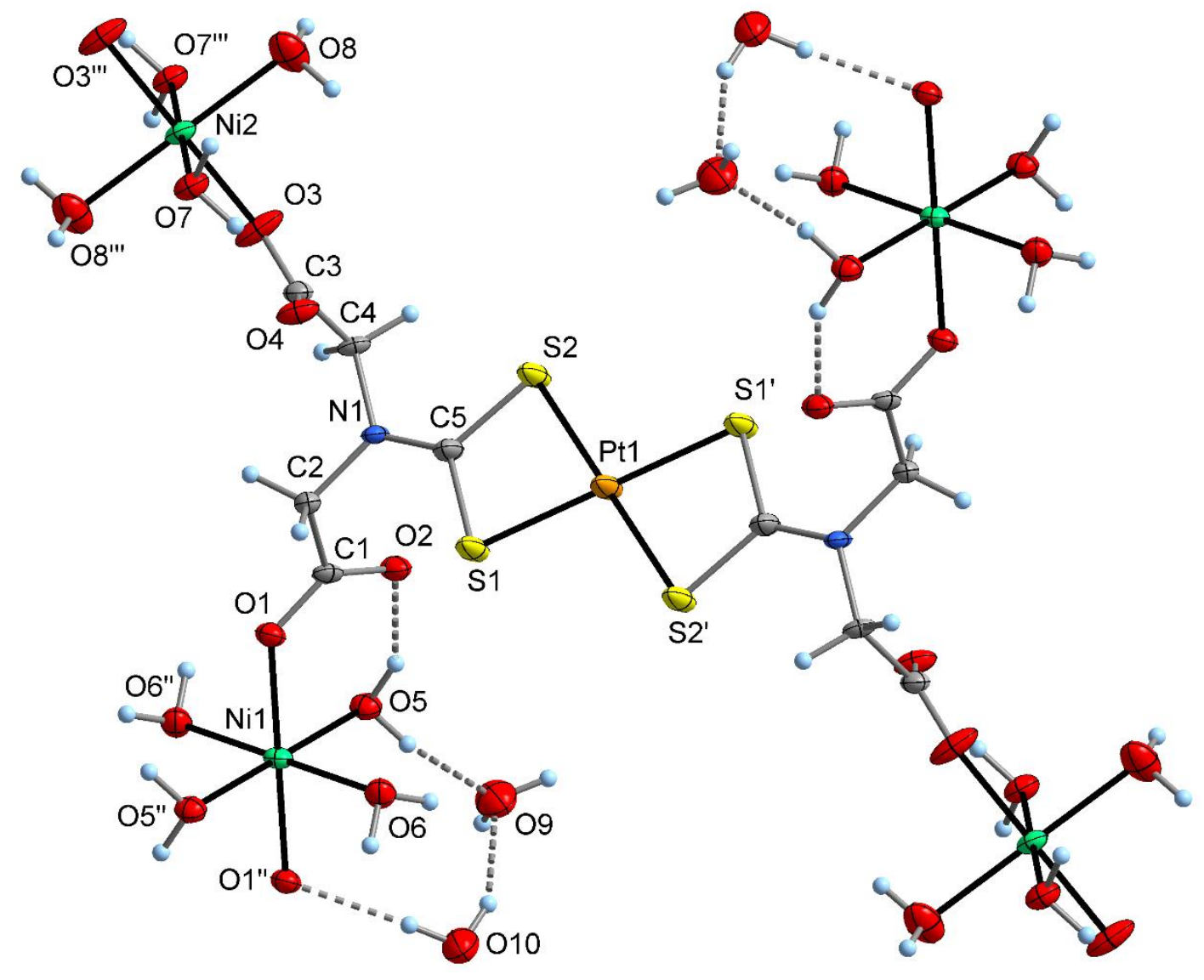

Figure S6. Molecular structure of $\mathrm{Ni}_{2}\left[\mathrm{Pt}(\mathrm{L})_{2}\right](2-\mathrm{Ni}) \cdot 12 \mathrm{H}_{2} \mathrm{O}$ in the crystal, showing the atom numbering scheme. Displacement ellipsoids drawn at the $50 \%$ probability level. The $\mathrm{Ni}$ and $\mathrm{Pt}$ atoms are situated on crystallographic centres of inversion. Selected intermolecular distances $(\mathrm{pm})$ and angles ( $\left.{ }^{\circ}\right)$ : Pt1-S1 230.99(9), Pt1-S2 232.03(8), Ni1-O1 206.6(2), Ni1-05 206.6(2), Ni1-O6 205.3(2), Ni2-O3 203.0(2), Ni207 204.9(2), Ni2-O8 207.3(3), C5-S1 172.1(3), C5-S2 173.0(3), C5-N1 130.6(4), S1-Pt1-S2 75.55(3), S1Pt1-S2' 104.45(3), O1-Ni1-O5 89.0(1), O1-Ni1-O5" 91.0(1), O1-Ni1-O6 91.0(1), O1-Ni1-O6" 89.0(1), O3Ni2-07 91.5(1), O3-Ni1-O7"' 88.5(1), O3-Ni2-08 91.6(1), O3-Ni2-O8"' 88.4(1), S1-C5-S2 110.6(2). 


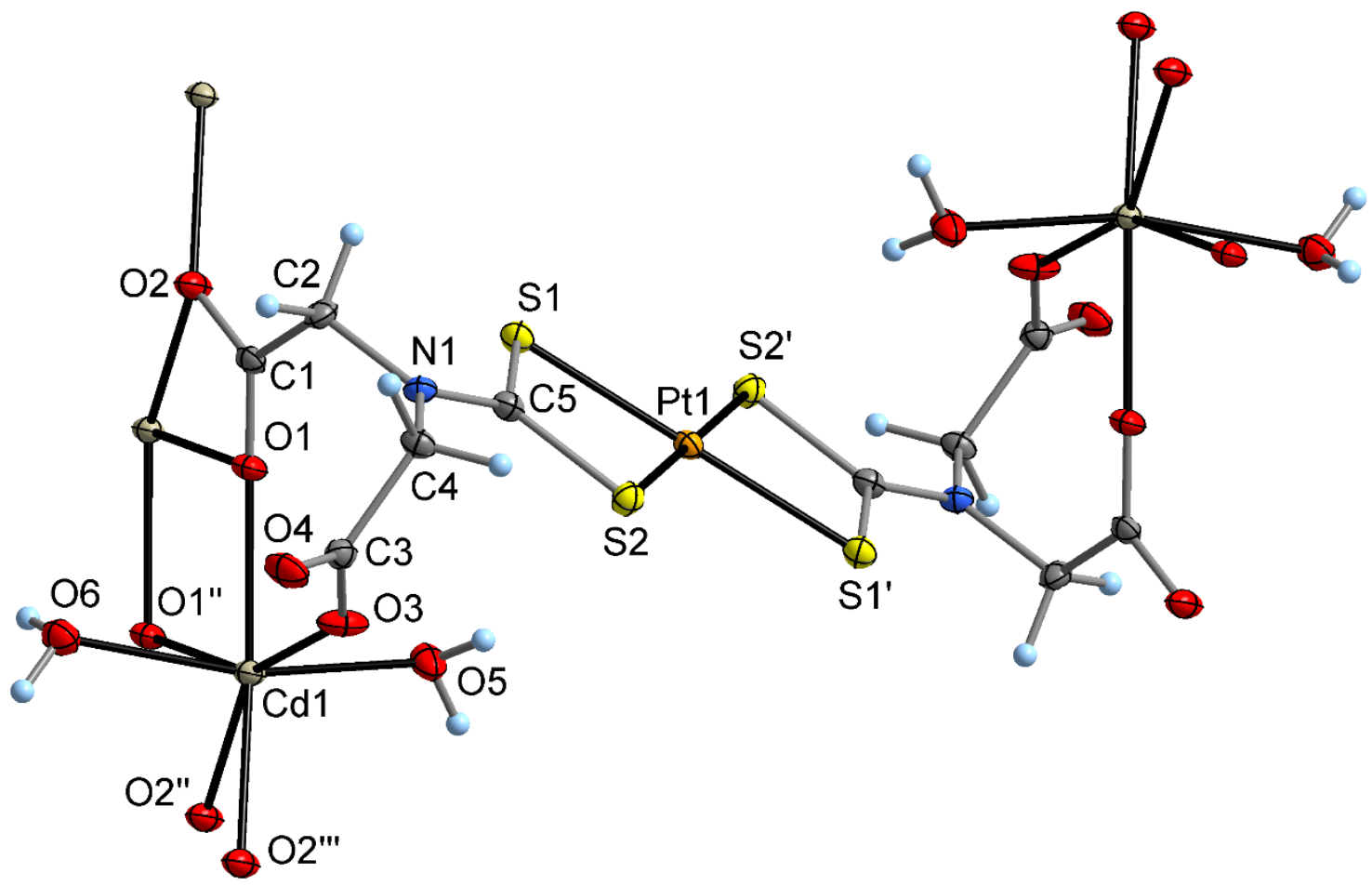

Figure S7. Molecular structure of $\mathrm{Cd}_{2}\left[\mathrm{Pt}(\mathrm{L})_{2}\right](2-\mathrm{Cd}) \cdot 4 \mathrm{H}_{2} \mathrm{O}$ in the crystal, showing the atom numbering scheme. Displacement ellipsoids drawn at the $50 \%$ probability level. The Pt atom is situated on a crystallographic centre of inversion. Selected intermolecular distances $(\mathrm{pm})$ and angles $\left({ }^{\circ}\right)$ : Pt1-S1 231.41(6), Pt1-S2 232.18(6), Cd1-01 236.1(2), Cd1-O1" 248.0(2), Cd1-O2" 246.5(2), Cd1-O2'"' 231.1(2), Cd1-O3 222.8(2), Cd1-O5 227.1(2), Cd1-06 227.1(2), C5-S1 172.1(2), C5-S2 172.7(2), C5-N1 131.5(3), S1-Pt1-S2 75.34(2), S1-Pt1-S2' 104.66(2), 01-Cd1-01" 71.54(7), 01-Cd1-O2" 121.95(6), O1-Cd1-O2'"' 168.41(7), O1-Cd1-O3 83.87(7), O1-Cd1-O5 82.38(7), O1-Cd1-O6 82.93(7), O1"'-Cd1-O2" 52.45(6), O1"-Cd1-O2"' 117.01(6), O1"'-Cd1-O3 155.40(7), 01"-Cd1-O5 90.71(7), O1"'-Cd1-O6 78.31(7), O2"Cd1-O2"' 68.60(8), O2"-Cd1-03 150.84(6), O2"'-Cd1-05 84.16(7), O2"'-Cd1-O6 98.05(7), O2'"'-Cd1-03 87.27(7), O2"''-Cd1-05 104.56(7), O2"''-Cd2-06 91.05(7), O3-Cd1-05 86.52(8), 03-Cd1-06 98.52(8), S1C5-S2 110.5(1). 


\section{Powder X-ray diffraction studies}

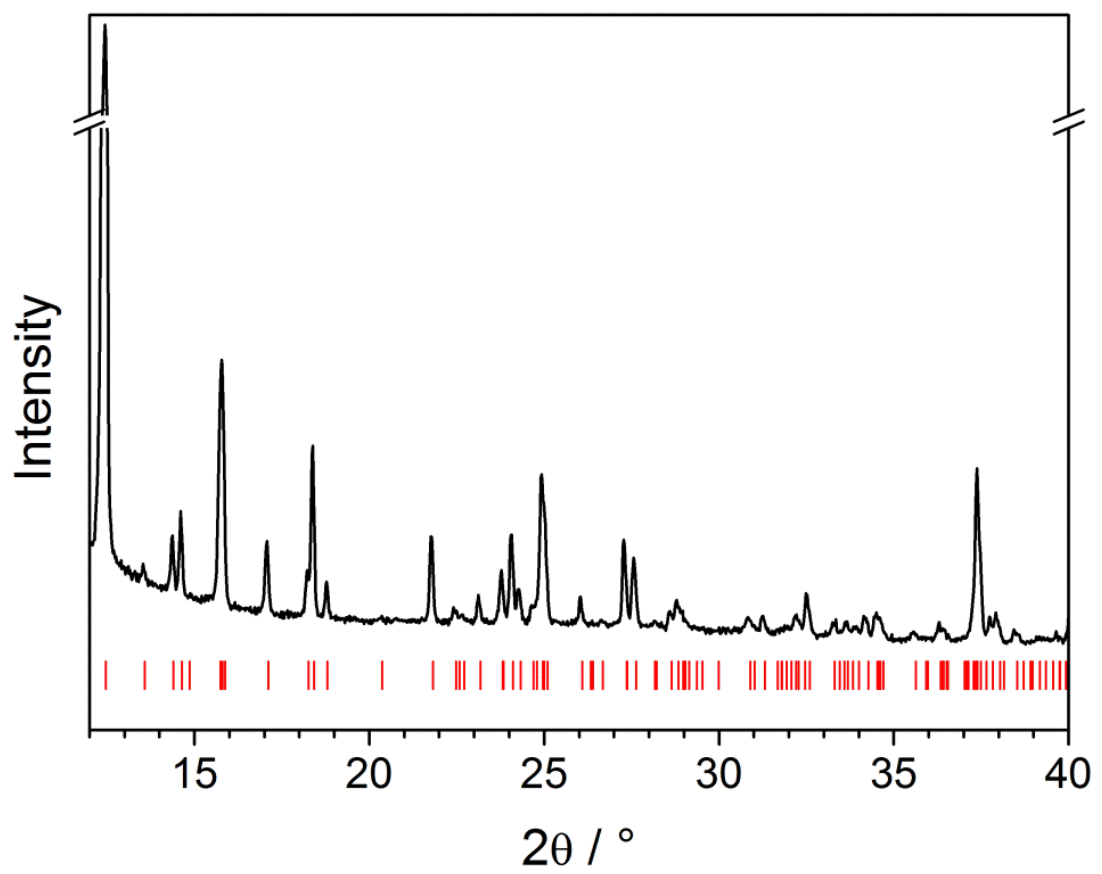

Figure S8. Powder X-ray diffraction pattern of $\mathbf{2}-\mathbf{S r} \cdot 4 \mathrm{H}_{2} \mathrm{O}$ as compared to the pattern calculated from single-crystal data (red bars). For better comparison, the used unit cell parameters were determined at room temperature: space group $\mathrm{P} \overline{1}$ (triclinic), $a=6.878(2) \AA, b=7.946(2) \AA, c=11.582(2) \AA, \alpha=$ $94.17(2)^{\circ}, \beta=100.80(2)^{\circ}, \gamma=114.99(2)^{\circ}$.

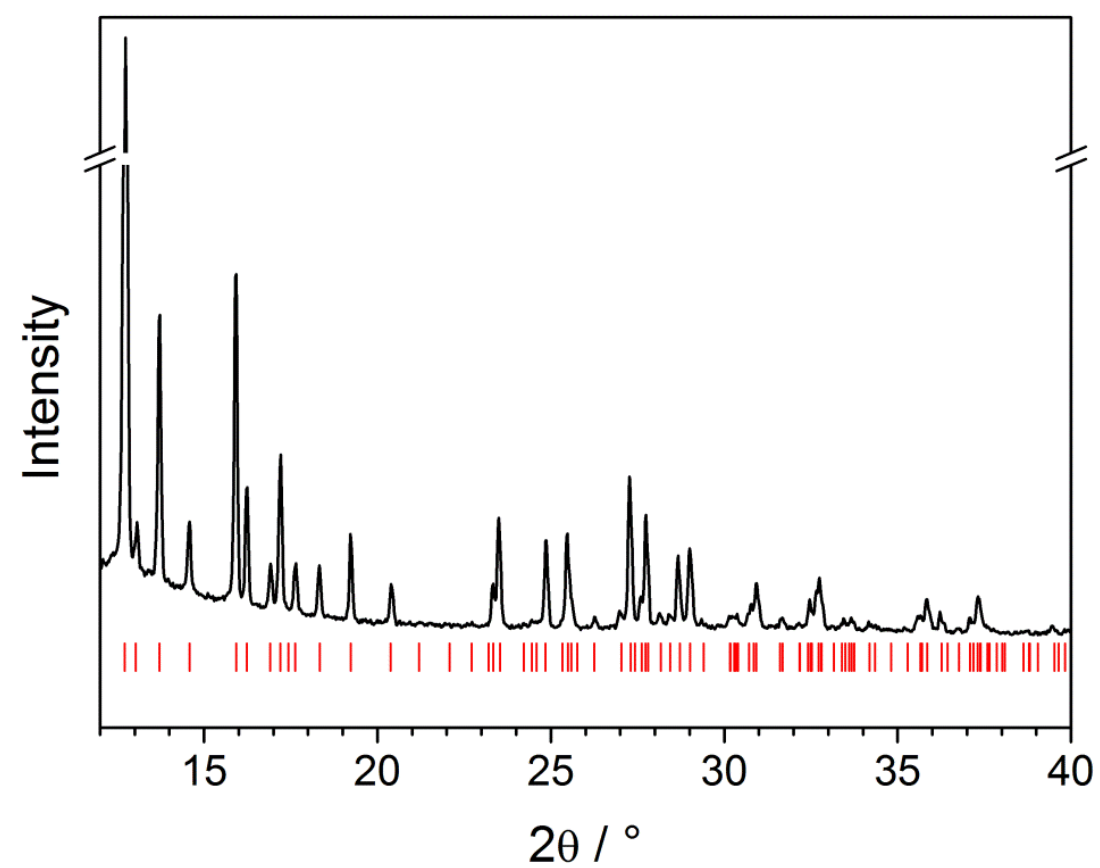

Figure 59. Powder X-ray diffraction pattern of 2-Cd.4 $4 \mathrm{H}_{2} \mathrm{O}$ as compared to the pattern calculated from single-crystal data (red bars). For better comparison, the used unit cell parameters were determined at room temperature: space group $\mathrm{P} \overline{1}$ (triclinic), $a=6.767(1) \AA, b=7.464(2) \AA, c=11.454(1) \AA, \alpha=$ $103.93(1)^{\circ}, \beta=96.78(1)^{\circ}, \gamma=103.77(1)^{\circ}$. 


\section{Thermal analyses}

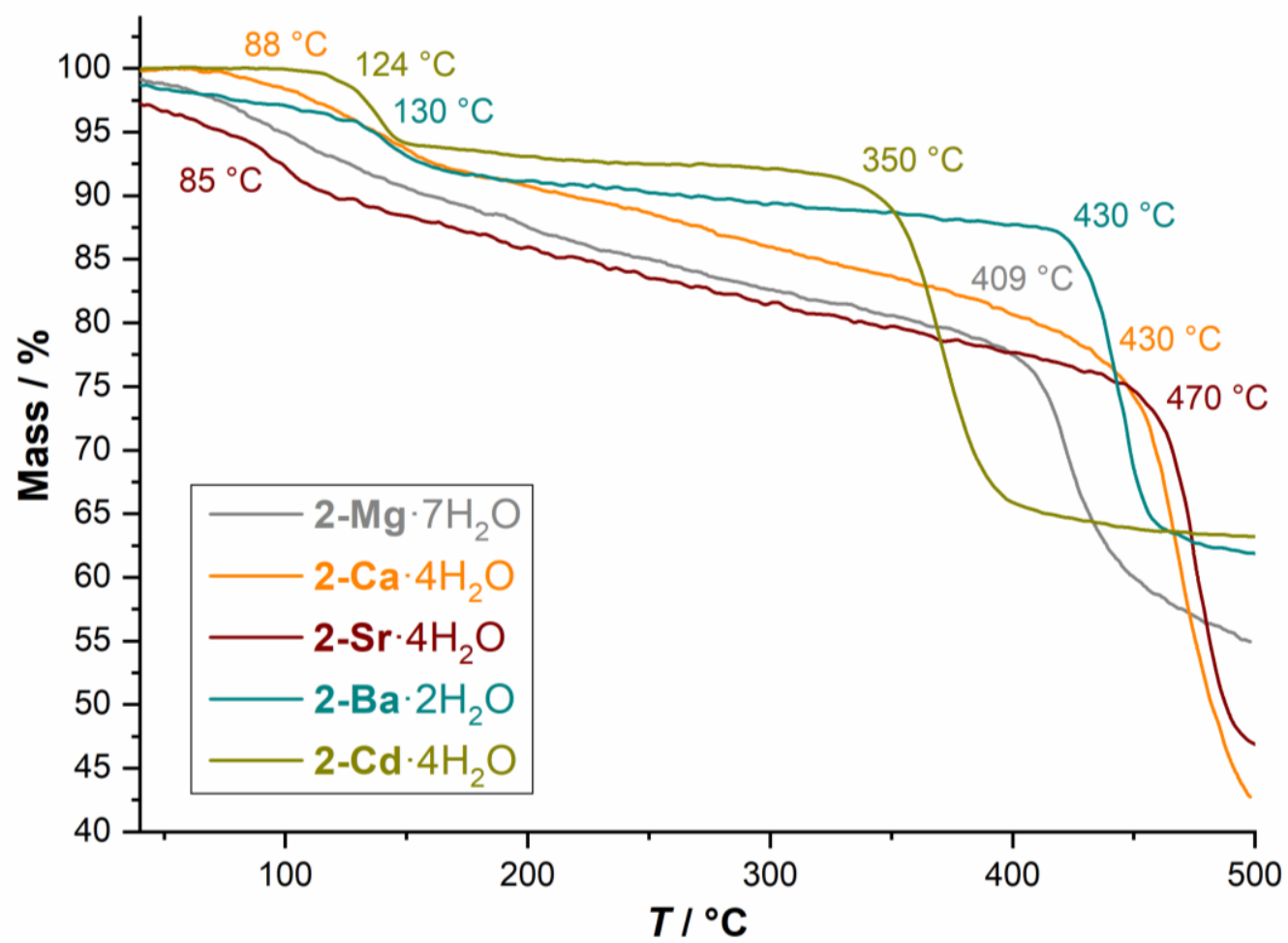

Figure S10. Thermogravimetric (TG) analyses of alkaline earth and cadmium compounds $\mathbf{2}$ under an inert atmosphere of nitrogen.

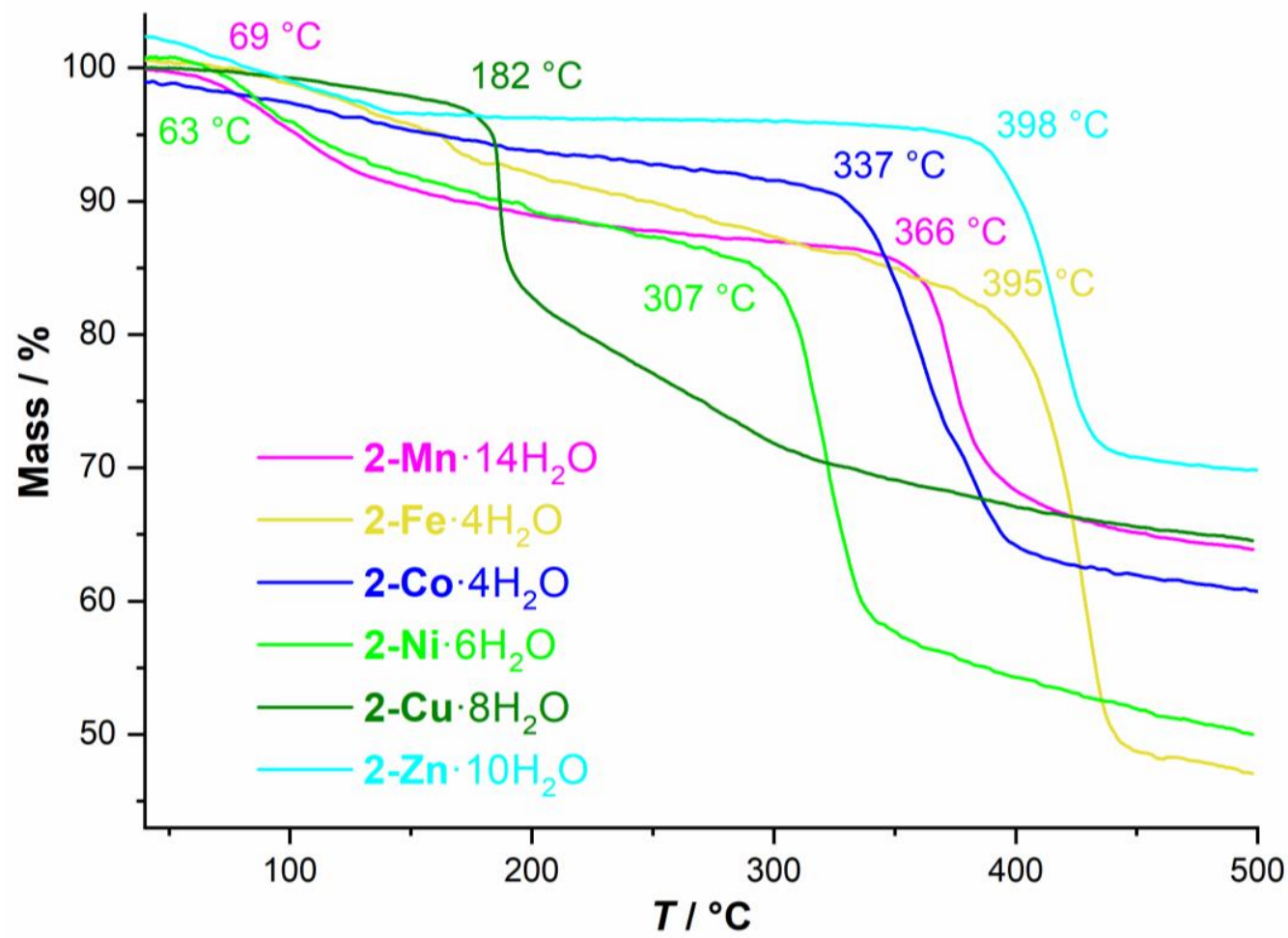

Figure S11. Thermogravimetric (TG) analyses of first-row transition metal compounds 2 under an inert atmosphere of nitrogen. 